\title{
Maximum Power Point Tracking by the Small-Signal-Based PI and Fuzzy Logic Controller Approaches for a Two-stage Switched-Capacitor DC-DC Power Boost Converter; Applicable for Photovoltaic Utilizations
}

\author{
Kübra BULUT ${ }^{\mathrm{a}}$, Davood GHADERI ${ }^{\mathrm{b}}$ \\ Electrical and Electronics Engineering Department, Bursa Technical University, Bursa, Turkey \\ davood.ghaderi@btu.edu.tr
}

Received/Geliș: 25.05 .2020

Accepted/Kabul: 00.00.2020

\begin{abstract}
For the Photovoltaic panels, one of the main troubles is generating the limited values of the voltage. To enhance this DC voltage for grid applications, high-voltage gain, transformer-less, low-voltage stress, and efficient DC-DC boost converters are used. The main concern is keeping the voltage constant at the output ends of the converter by changing the voltage of the PV array or the value of the load under the maximum power of the array through the simple control approaches. This approach is well-known as the Maximum Power Point Tracking (MPPT). This study presents the control process for the Two-stage Switched-Capacitor (SC) cell-based boost converter with Proportional Integral (PI) and fuzzy logic controller methods. Two-stage SC cell-based boost converter has been used instead of the conventional boost converter to provide higher voltage gain and lower voltage stresses on the power switch. In the proposed study, the voltage gain and efficiency of the boost converter are computed utilizing the method of the inductors volt-second balance and capacitor current-charge approaches. The compared systems were tested at different input voltages, and the output voltage is fixed at 200 VDC. Results exhibit the comparison between PI controller and fuzzy logic controller algorithms applied to the converter. In this article, MATLAB / SIMULINK software was utilized. The final results demonstrate that the fuzzy logic controller has quicker performance compared with PI Control but the PI controller has less overshoots and undershoots at the change time of the input voltage or output load.
\end{abstract}

Key words : Photovoltaic panel; switched-capacitor cell; dc-dc boost converter; PI Controller; fuzzy logic

\section{Fotovoltaik Kullanımlar için Uygulanabilir, İki Kademeli Anahtarlamalı Kapasitör Tabanlı DC-DC Yükseltici Dönüştürücü için Küçük Sinyal Bazlı PI ve Bulanık Mantık Denetleyicisi Yaklaşımlarıyla Maksimum Güç Noktası Takibi}

\begin{abstract}
Öz: Fotovoltaik paneller için esas problemlerden biri de voltajın sınırlı değerlerde üretilmesidir. Şebeke uygulamaları için bu DC voltajını arttırmak için, yüksek voltaj kazanclı, trafosuz, düşük voltaj stresi ve verimli DC-DC yükseltici dönüştürücüler kullanılır.Esas olan, basit kontrol yaklaşımları ile PV dizisinin gerilimini veya dizinin maksimum güç altındaki yük değerini değiştirerek voltajı dönüştürücünün çıkış uçlarında sabit tutmaktır.Bu yaklaşım Maksimum Güç Noktası İzleme (MPPT) olarak bilinir. Bu çalışma, Orantılı İntegral (PI) ve bulanık mantık denetleyici yöntemlerine sahip İki Aşamalı Anahtarlamalı Kapasitör (SC) hücre tabanlı boost dönüştürücü için kontrol sürecini sunar. Güç anahtarı üzerinde düşük voltaj stresleri ve daha yüksek voltaj kazancı sağlamak için geleneksel yükseltici dönüştürücü yerine iki aşamalı SC hücre tabanlı yükseltici dönüştürücü kullanılmıştır. Önerilen çalışmada, yükseltici dönüştürücünün voltaj kazancı ve verimliliği, volt-ikinci denge yöntemi ve akım şarj yaklaşımları kullanılarak hesaplanmıştır. Karşılaştırılan sistemler farklı giriş voltajlarında test edilmiştir ve çıkış voltajı 200 VDC'ye sabitlenmiştir.Sonuçlar, dönüştürücüye uygulanan PI denetleyicisi ile bulanık mantık denetleyicisi algoritmaları arasındaki karşılaştırmayı gösterir. $\mathrm{Bu}$ makalede MATLAB / SIMULINK yazılımı
\end{abstract}


kullanılmıştır. Nihai sonuçlar, bulanık mantık denetleyicisinin PI Kontrolü ile karşılaştırıldığında daha hızlı performansa sahip olduğunu, ancak PI denetleyicisinin giriş voltajının veya çıkış yükünün değişim süresinde daha az aşma ve aşınmaya sahip olduğunu göstermektedir.

Anahtar Kelimeler: Fotovoltaik panel; anahtarlamalı kapasitör hücresi; dc-dc yükseltici dönüştürücü; PI Denetleyici; bulanık mantık

\section{Introduction}

Renewable energy is gaining importance today due to increasing energy demand and decreasing classical resources. At the same time, the damage caused by fossil fuels to both the human and the environment is moderate. Global warming, climate changes, rises at sea level are among the main damages. Renewable energy is important in reducing all these negative effects. Hydroelectric, solar, geothermal, wind, and clean energy sources are all, but the most popular among them is solar energy [1-3]. Solar energy is an inexhaustible source of energy and is not affected by negativities such as global warming. Rays coming from the sun are directly converted into electrical energy. Photovoltaic panels are used to obtain electricity from solar energy. Solar energy is one of the most popular energy sources that many researchers are working on because it is clean, pollution-free, and infinite and can meet our demands without disturbing the environment. To reduce conventional energy use, the PV source is integrated into the grid via power converters [4-6].

Solar energy is an unlimited source of energy on earth. The absence of mains power in the rural area makes solar energy a better alternative. Therefore, independent PV systems can be used in rural areas. The solar photovoltaic system can also be connected to the grid to use PV power. Photovoltaic panels cannot provide system output power stability due to factors such as radiation, temperature, and shading. At the same time, solar panel efficiency depends on solar cell materials and the control mechanism used. For these reasons, a new control mechanism, the Maximum Power Point Tracking (MPPT) algorithm, is used to obtain maximum power from the PV array. This results in increased efficiency of solar modules and improved system performance [7-10]. Many MPPT methods have been designed in recent years. These techniques are divided into two as direct and indirect control approaches. In the indirect control method, the real power of the photovoltaic panel output cannot be continuously calculated. The process of producing the control signal needed in the control process in this method depends on the characteristic features of the photovoltaic cell such as open-circuit voltage, short-circuit current, radiation intensity, and module temperature. In the direct control method, the real power of the photovoltaic panel output is continuously read and a converter reference signal is created, which is required to reach the real maximum power-point. Although indirect control methods are fast, they depend on the photovoltaic panel characteristic and therefore cannot provide true MPPT control. Although direct control methods are slower than indirect control methods, they are independent of the photovoltaic panel characteristic. Therefore, direct control methods are preferred for providing true MPPT [11]. In this study, the direct method was developed by using small-signal based PI and fuzzy logic controllers to monitor the maximum power of the photovoltaic system.

It is evident how important DC-DC power boost converters are in providing maximum efficiency from solar energy, and amplifier DC-DC converters are more preferred in photovoltaic panels. These converters convert the direct current voltage at the input to another higher level direct current voltage. They provide high frequency, high power, and better performance. Photovoltaic panels alone produce insufficient power. It is necessary to use a DC-DC boost converter to bring this voltage to the desired level. Various DC-DC boost converter topologies are available.

DC-DC boost converters are utilized to enhance the input voltage. They have isolated or nonisolated construction. Isolated converters increase the voltage by utilizing a high voltage 
transformer (HVT). There are two diverse ways of procuring high voltage gain. The first is to arrange the transformation rate of HVT; the second is to utilize voltage multiplier circuits on the auxiliary side of the HVT [12-15]. However, these techniques are not alluring, because they increment the expense and size of converters and reduce the operating life of PV modules. Besides, the efficiency of the converter abates. On the other hand, Non-isolated converter is not suitable to utilize in high voltage, on account of the output voltage on the diode and switch is equivalent to the output voltage. Much of the researches have been done about DC-DC boost converters. There are many ways for this. Some investigators have worked on limitation switching loss while others have researched to limit conductivity loss. The researchers continue their research to get higher performance from the converters and to increase the voltage gain [16-20].

In this study, performance analysis was performed by adding a 2-stage switched-capacitor (SC) cell to the boost converter. This block helps to increase the input voltage to a higher level and at the same time, decrease the voltage stress on the power switch by parallel and serial configuration of the capacitors for the on and OFF-states of the power switch. Also, one of the main important features of the selected boost converter is its ability to work with lower duty cycles that can directly decrease the dynamic losses of the converter due to lower currents values in all of the components and especially the power switch. This directly increases efficiency. Also, the other specification of the converter is that it includes only one power switch that can decrease the complexity of the control circuit and make it more possible to be implemented. The effect and efficiency of the proposed converter on the voltage gain were analyzed. To stabilize the DC-DC boost converter output voltage and obtain high performance in terms of efficiency, converter control is important. Control methods such as fuzzy logic, PI (Proportional-Integral), PID (Proportional-IntegralDerivative), soft switching are available and are used to reduce the influence of external factors such as mechanical vibrations of the system. The fuzzy logic control method is preferred more because of its easy application and fast response-ability features. It is based on human experience about the investigated system. System complexity is not included, as it does not require a mathematical model like other control methods. Also, a small-signal analysis-based PI controller is introduced in this study and the performance of this controller is compared with the Fuzzy controller. A large mathematical investigation is presented for this controller and results are crosschecked by the results for the Fuzzy controller. In this study, the converter part and the control of the photovoltaic system are examined in detail.

\section{Analysis for the Projected DC-DC Converter}

The 2-stage SC-cell based boost converter is improved from the conventional boost converter by introducing a 2-stage $\mathrm{SC}$ cell as a voltage double structure $[9,21]$. The principal reason for utilizing SC techniques with the traditional boost converter is to abate switch ON-time while it provides a higher output voltage. Consequently, the current ripple is reduced, and it results in decreasing the conduction losses. Figure 1 demonstrates the 2-stage SC-cell-based DC-DC boost converter. 


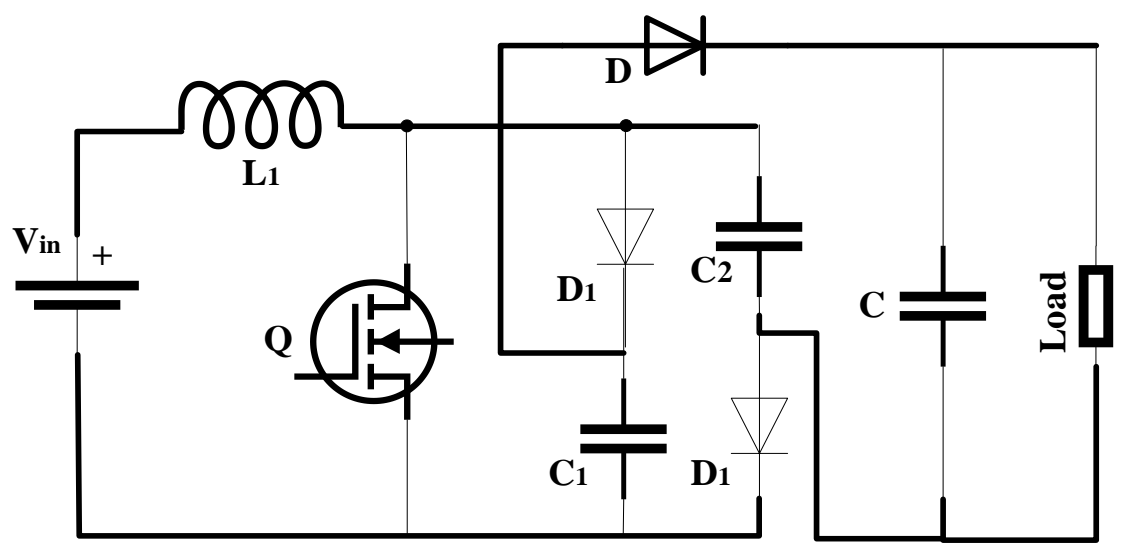

Figure 1. 2-Stage SC-cell based DC-DC boost converters [9,21].

\subsection{Operating Modes Based on 2-Stage SC-Cells}

The boost converter based on 2-stage SC-cells in continuous current mode (CCM) can be investigated in two different operational modes including the ON and OFF-time intervals of the power switch. The states of the components and the connection of the power diodes and switch are analyzed separately for these two working modes.

Mode 1 [0-DT]: For the first time interval, since the power switch is activated, the input voltage source Vin charges the inductor L. Capacitors $C_{1}$ and $C_{2}$ compose a loop to supply the load current via the closed switch $\mathrm{Q}$ as shown in Figure 2a. In this working mode, both capacitors are in discharging mode, the inductor is charging through the power switch and diode D is working in ON-state condition. Since both of the diodes, $\mathrm{D}_{1}$ and $\mathrm{D}_{2}$ are deactivated, voltages across capacitor $\mathrm{C}_{1}$ is discharging on the load by this diode and voltage across the capacitor $\mathrm{C}_{2}$ discharges on the power switch. Output capacitor $\mathrm{C}$ is charging in this state to be ready for supplying the current of the load for the next time interval.

Mode 2 [DT-T]: For the second state, since the power switch is deactivated, the capacitors $\mathrm{C}_{1}$ and $C_{2}$ are charged via $D_{1}$ and $D_{2}$ in parallel in Figure 2b. Charging is done through the inductor L. For this working mode, capacitors absorb the voltage through the inductor to transfer to the load for the next working mode. In this state, diode $\mathrm{D}$ is deactivated since the voltage at the cathode is rather than anode that is connected to the inductor through diode $\mathrm{D}_{1}$. The current of the load is supplying by output capacitor $\mathrm{C}$.

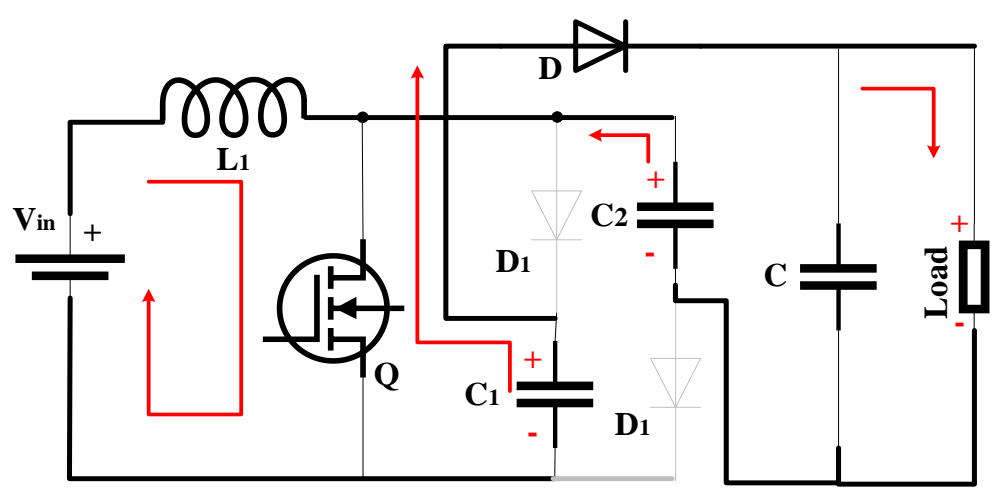

(a) 


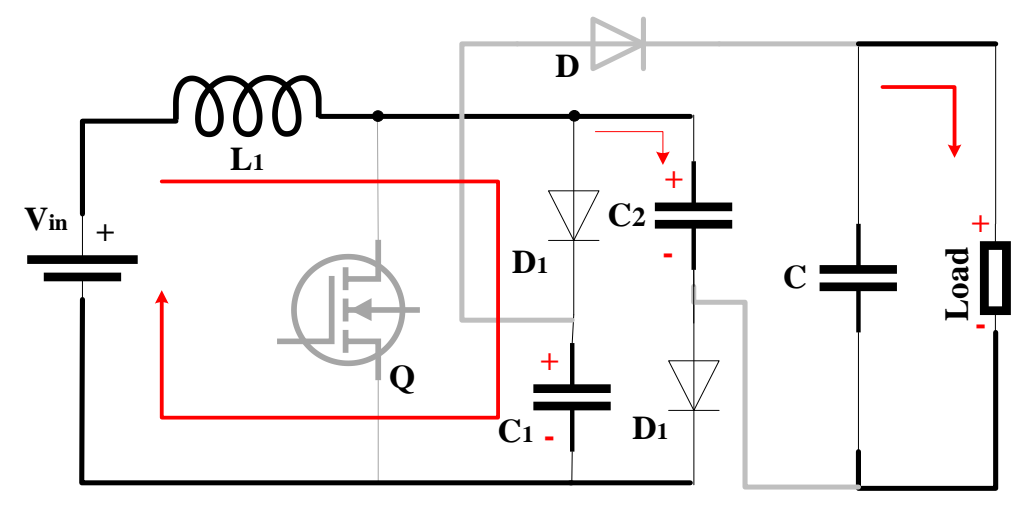

(b)

Figure 2. Configuration of the proposed converter and states of the components, when the power switch is working in; (a) ON and (b) OFF states.

In Figure 3, the steady-state waveforms are shown for the components of the converter. This figure shows that for the time interval that the power switch receives the pulse at the gate-source pins and is activated, the inductor begins to be charged through the power switch and both cell-capacitors $\mathrm{C}_{1}$ and $\mathrm{C}_{2}$ begin to be discharged. Also, for the next time interval, by deactivation of the power switch, the current of the inductor decreases since the voltage on the inductor is being negative and capacitors begin to be charged.

2-Stage SC boost converter is utilized for increasing the efficiency and voltage gain. This will do by applying components like capacitors that ideally don't lose any amount of the power and also cause to follow lower amounts of the current through the components since they act as voltage-doubler in the projected configuration. But for the implementation, all components lose power since they include the internal resistances. Figures 4 and 5 express the circuit models by considering the component's internal resistance when the switch is activated and deactivated, respectively.

Figure 4 demonstrates the parasitic resistive elements. The power is transferred to the load with the connection of the capacitors $\mathrm{C}_{1}$ and $\mathrm{C}_{2}$ (where $\mathrm{V}_{\mathrm{C} 1}=\mathrm{V}_{\mathrm{C} 2}$ ) when the switch is in ON-mode. In this way, half of the output voltage is dropped on these capacitors while the rest of the output voltage is supplied to the load. Figure 5 shows that capacitors $C_{1}$ and $C_{2}$ are charged via the inductor L by a parallel combination. The switch state is OFF for this model. So, due to the parallel connection, the total value of the voltage on capacitors $C_{1}$ and $C_{2}$ is equal to the voltage through the output capacitor $\mathrm{Co}$ and this situation is expressed by Equation (1) [9].

$$
V_{C 1}+V_{C 2}=V_{C}
$$

Figure 6 shows the waveforms of inductor voltage and output capacitor current according to Figure 4 and Figure 5 when the power switch is working in ON and OFF states. Equations are composed using Kirchhoff's current and voltage laws. Here, Vo is the output voltage, I is the inductor current the Vin is the input voltage, $R_{\text {load }}$ is the load resistance and $D$ is the duty cycle of the power switch. Also, non-ideal inherent resistive elements are the series inductor $R_{L}$, power switch $R_{Q}$ and diode resistance $R_{D}$, and the diode threshold voltage is shown with $V_{D}$. As seen in Figure 6 , voltage decline on $\mathrm{R}_{\mathrm{D} 1}$ and $\mathrm{R}_{\mathrm{D} 2}$ eliminates each other's impact because of opposite polarities. 


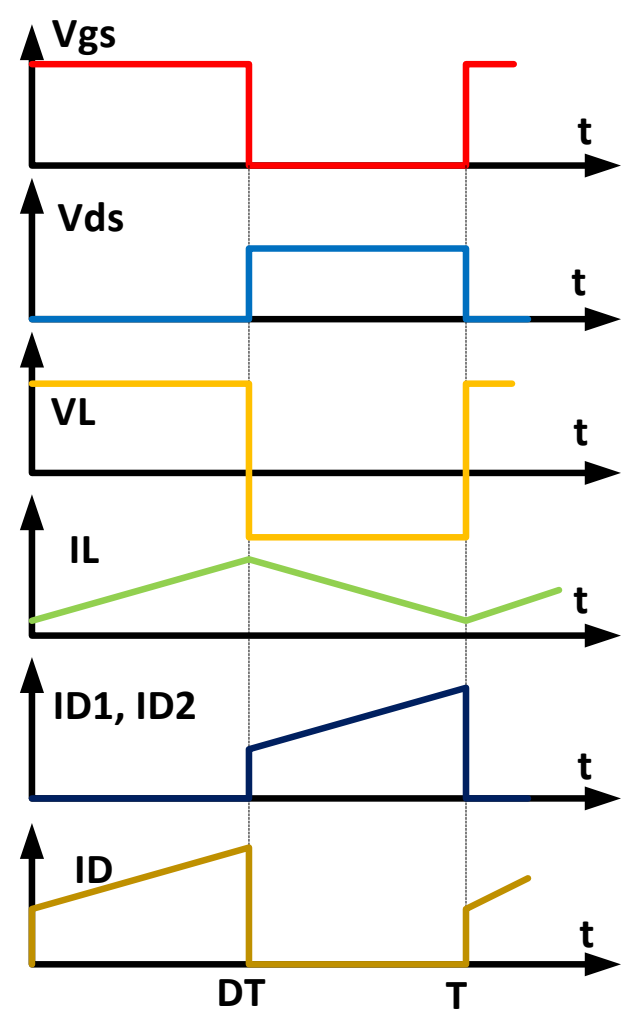

Figure 3. The waveforms in CCM mode for 2-stage SC-cell based boost converter.

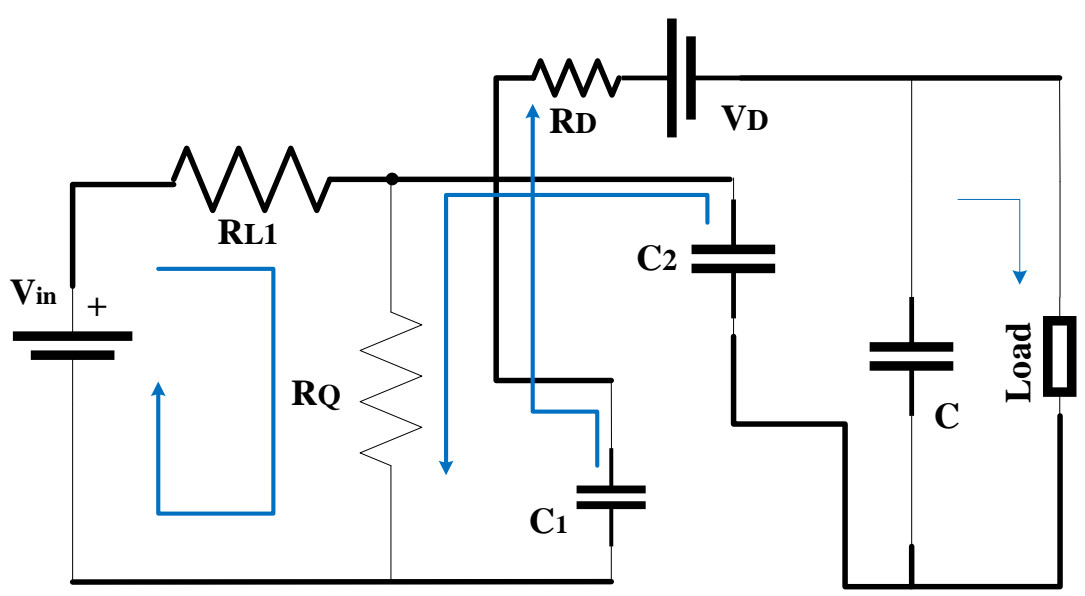

Figure 4. The parasitic resistive elements of the proposed converter when the power switch is working in ON-state.

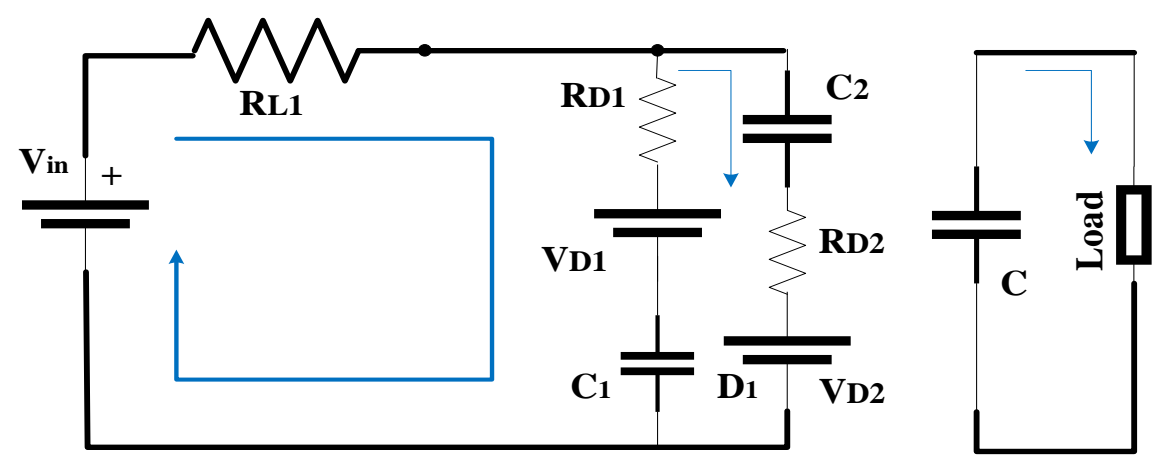

Figure 5. The parasitic resistive elements of the proposed converter when the power switch is working in OFF-state. 


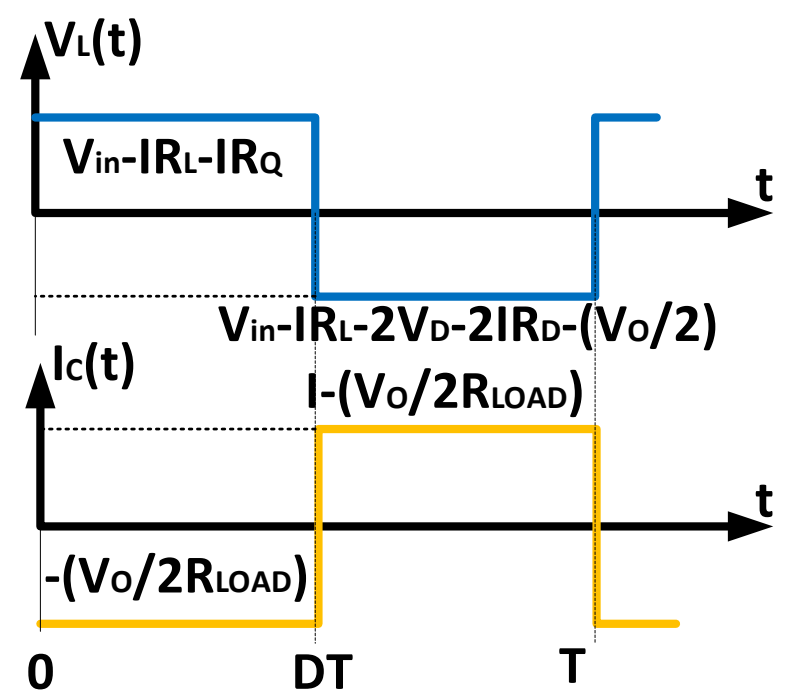

Figure 6. Waveforms of inductor voltage and output capacitor current in CCM [21].

The volt-second balance and current charge balance have been used for determining the voltage of the inductor and current of the capacitor. In this way, Equality (2) and (3) can be written;

$$
\begin{array}{ll}
\text { For } \mathrm{V}_{\mathrm{L}} & \longrightarrow \quad \text { D. }\left(V i n-I R_{L}-I R_{Q}\right)+(1-D) \cdot\left(V i n-I R_{L}-2 V_{D}-2 I R_{D}-\left(\frac{V_{\text {in }}}{2}\right)\right) \\
\text { For } \mathrm{i}_{\mathrm{C}} \longrightarrow & \text { D. }\left(-V_{0} / 2 R_{\text {load }}\right)+(1-D) \cdot\left(I-\frac{V_{0}}{2 R_{\text {load }}}\right)=0
\end{array}
$$

When Equation (2) and Equation (3) are arranged, the following equations are obtained.

$$
\begin{array}{r}
\operatorname{Vin}-I R_{L}-I D R_{Q}-2 I .(D-1) \cdot R_{D}-2(1-D) \cdot V_{D}-(1-D) \frac{V_{O}}{2}=0 \\
I .(1-D)-\left(\frac{V_{O}}{2 R_{\text {load }}}\right)=0 \longrightarrow L=\frac{V_{\text {in }}(\max )\left(V_{o}(\max ) V_{\text {in }}(\max )\right)}{\Delta i_{L} f_{s} V_{O}(\max )}
\end{array}
$$

Equation (5) is written instead of current (I) in Equation (4), and gain is obtained. The static gain G $=\mathrm{Vo} / \mathrm{V}$ in is explained by Equation (6).

$$
G=\frac{V o}{V i n}=\left(\frac{2}{(1-D)}\right)\left(1-\frac{2(1-D) V_{D}}{\operatorname{Vin}}\right)\left(\frac{1}{1+\frac{R_{L}+D R^{+2 R_{D}(1-D)}}{(1-D)^{2} \cdot R_{\text {load }}}}\right)
$$

Equation (7) can be written for voltage gain $\mathrm{G}$, when parasitic elements are neglected.

$$
G=\frac{2}{1-D}
$$

Consequently, the efficiency is expressed as;

$$
\eta=(1-D) \frac{V_{C 1,2}}{\operatorname{Vin}}
$$


$\mathrm{V}_{\mathrm{C} 1}=\mathrm{V}_{\mathrm{C} 2}$ is equal to $\mathrm{Vo} / 2$, thus efficiency is written according to Equation (9) and (10).

$$
\begin{gathered}
\eta=(1-D) \frac{V o}{2 \operatorname{Vin}} \\
\eta=\left(\frac{\left(1-\frac{2(1-D) V_{D}}{V_{\text {in }}}\right)}{1+\frac{R_{L}+D R_{Q}+2 R_{D}(1-D)}{(1-D)^{2} \cdot R_{\text {load }}}}\right)
\end{gathered}
$$

\subsection{Parameters}

\subsubsection{Boost Inductor}

For inductance selection, the inductor ripple current should be limited to $30-40 \%$ of output current. For instance, if the wave-current is restricted to $40 \%$ for $45 \mathrm{~V}$ of input voltage, the $\Delta \mathrm{i}_{\mathrm{L}}$ is equal to 1.2A using Equation (11).

$$
{ }^{\Delta i} L=(0.3-0.4) i_{o}(\max ) \cdot \frac{V_{o}(\max )}{V_{\text {in }}(\min )}
$$

Input voltage is between 45 to $60 \mathrm{~V}$ and $\left.\operatorname{Vin}_{(\max }\right)$ is maximum input voltage. Inductor value is calculated by using ripple current $\Delta \mathrm{iL}=1.2 \mathrm{~A}$ and switching frequency fs $=100 \mathrm{kHz}$. L (inductor value) is equal to $0.3 \mathrm{mH}$ according to Equation (12).

$$
L=\frac{V_{\text {in }}(\max )\left(V_{o}(\max )-V_{\text {in }}(\max )\right)}{\Delta i_{L} f_{s} V_{o}(\max )}
$$

\subsubsection{Output Capacitor}

The output capacitor should be chosen properly to accomplish the ideal output voltage ripple. Equality (13) is used for this.

$$
C=\frac{D \cdot i_{o}(\max )}{f_{s} \Delta V_{o}}
$$

Io(max) is the maximum output current for $130 \mathrm{~W}$ system and $\Delta \mathrm{V}_{\mathrm{O}}$ is the output voltage ripple. $\Delta \mathrm{V}_{\mathrm{O}}$ is requested to be $1 \%$. Therefore, the value of output capacitor $\mathrm{C}$ was selected as $333 \mu \mathrm{F}$ as the expected output voltage was $200 \mathrm{~V}$.

\subsubsection{SC-cell Capacitors}

The capacitors $\mathrm{C}_{1}$ and $\mathrm{C}_{2}$ compose a loop in series to supply the load via the closed switch Q. Io(max) is the average current which the capacitors transfer to load when the power switch is working in OFF state. If the output voltage ripple $\Delta \mathrm{V}_{\mathrm{O}}$ is expected as $1 \%$, capacitors value is $3.3 \mu \mathrm{F}$ according to Equation (14).

$$
C 1=C 2=\frac{i_{\text {O(MAX })}}{f_{s} \Delta V_{o}}
$$




\section{Fuzzy Logic Controller}

The fuzzy logic control method has been preferred in recent years because it is simple and doesn't need mathematical models. Its operation depends on human information and way of thinking. Fuzzy logic control technique has a rule base and consists of If-then rules. The essential idea of fuzzy logic is utilizing a variable whose values are words (such as small and large) rather than a number [22]. Figure 7 exhibits the parts of the fuzzy logic controller. The fuzzy logic controller comprises of four classifications. These are fuzzification, fuzzy rule, an inference engine and the de-fuzzification.

\subsection{Fuzzification}

Real values of $\mathrm{E}$ and $\mathrm{CE}$ are converted into linguistic fuzzy variables by using membership functions. The linguistic variables express as PB (positive big), PS (positive small), Z0 (zero), NS (negative small), NB (negative big). The Fuzzy logic controller has the inputs of the error (E) and the change of error (CE) that are shown in Equation (15) and (16). Duty cycle (D) is located at the output. Also, the control is done by changing this duty ratio according to the slope $\mathrm{E}(\mathrm{k})$ to bring back the operation point on the optimal point where the slope is zero [23]. E and CE is as follow;

$$
\begin{aligned}
& \text { Error }(E)=\text { Reference voltage }\left(V_{\text {ref }}\right) \text { - Output voltage }\left(V_{O}\right) \\
& \text { Change of Error }(C E)=\text { Error }(E) \text { - Previous Error }\left(V_{\text {pre }}\right)
\end{aligned}
$$

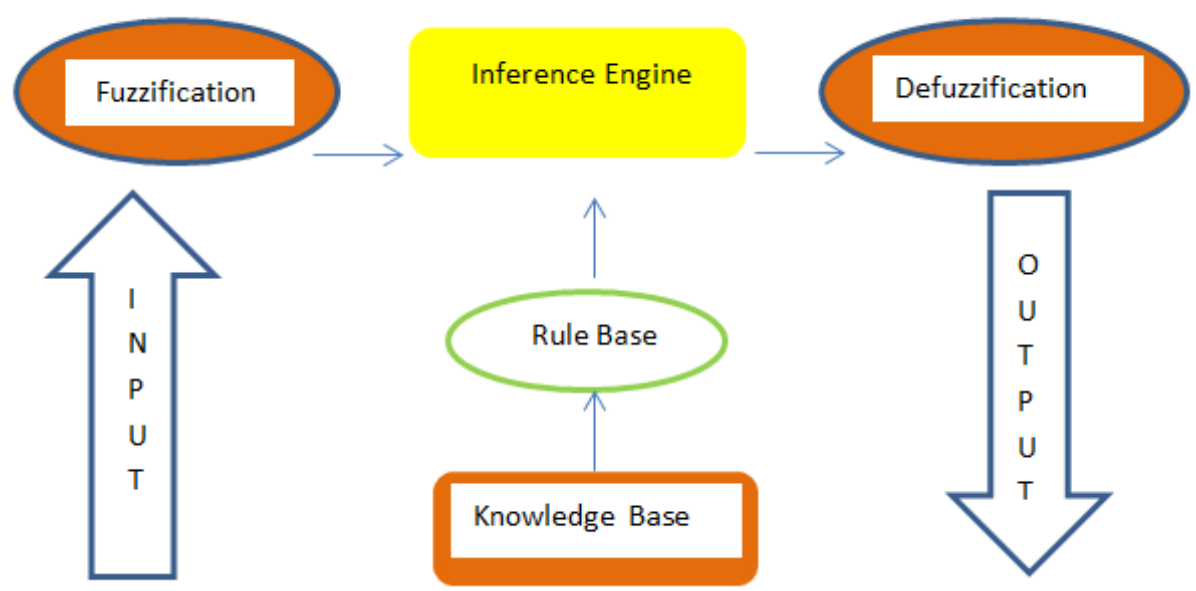

Figure 7. The main components of Fuzzy logic controller.

The range of saturation value of error (E) and change error (CE) is $[-1,1]$. To accomplish this range, a gain block is added for the input of fuzzy logic error and error change. The saturation blocks placed before these entries have prevented the over of limit. While the value of the error saturation block in Figure 8 is $[-600,600]$, the value of the change error saturation block is $[-11]$. In this way, when the values from these blocks are multiplied by the respective gains, the result will be in the range [-1 1]. 


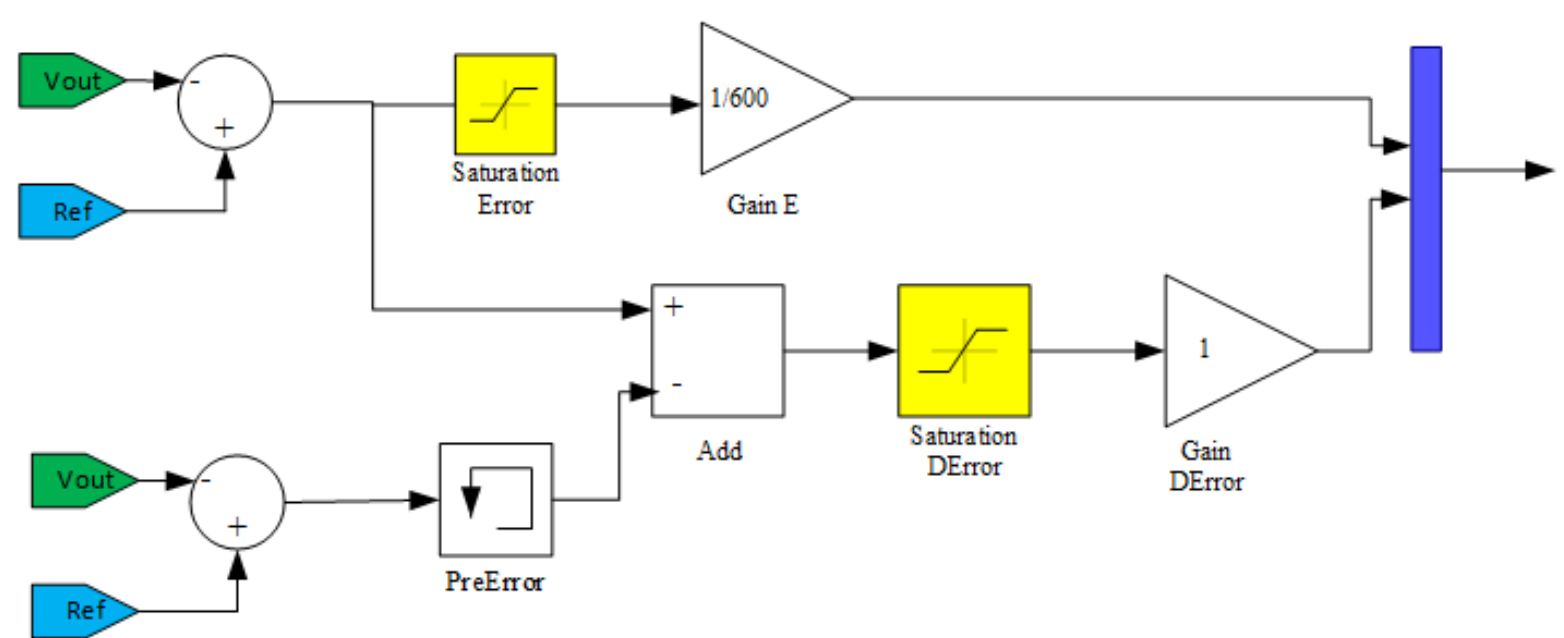

Figure 8. Fuzzy logic controller input variables.

The range of the output of the controller is $[-1,1]$ and there is an output gain block. The subsequent value is added to the past value and its saturation value enters the block where the pulse-width modulator (PWM) is produced. Figure 9 shows the fuzzy logic controller output variables.

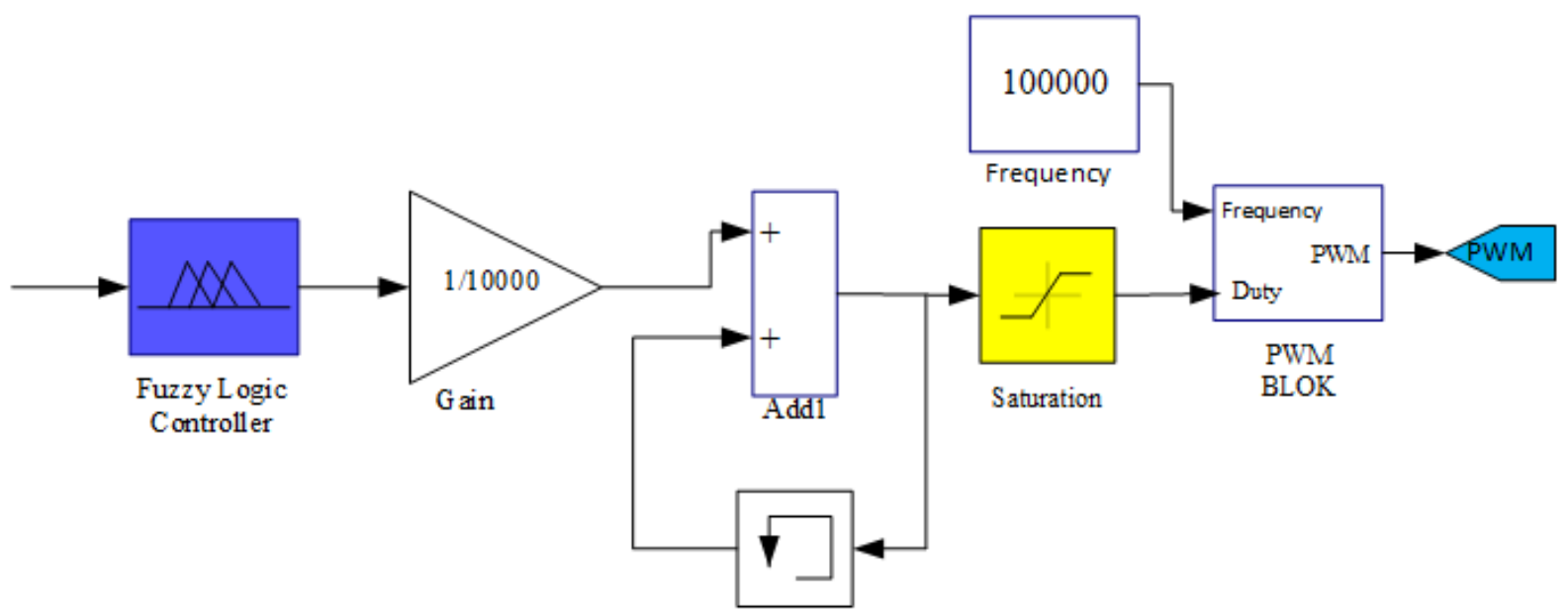

Figure 9. Fuzzy Logic Controller output variables.

\subsection{Fuzzy Rule and Inference Engine}

Fuzzy rule base consists of if-then functions that provide fuzzy inputs. The fuzzy inference engine formulates a logical decision based on the fuzzy rule. The fuzzy rules depend on human information and way of thinking and are converted lingual output in this part. In this study, the fuzzy inference method has been used with a max-min operation fuzzy combination [9].

The membership functions determined for the error are shown in Figure 10. These functions are NB / NM / NS / Z / PS / PM / PB. 


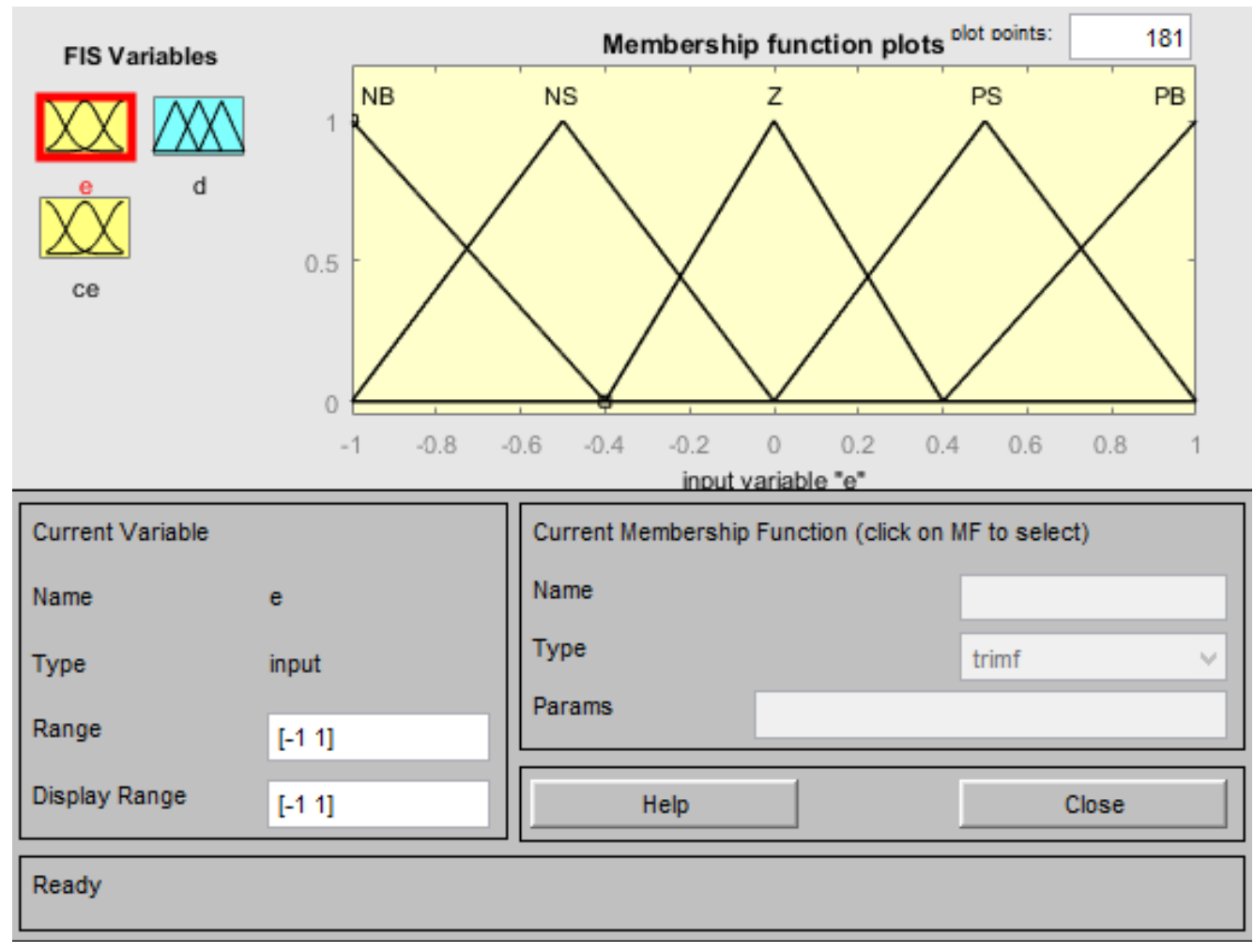

Figure 10."Error" input membership functions for fuzzy logic.

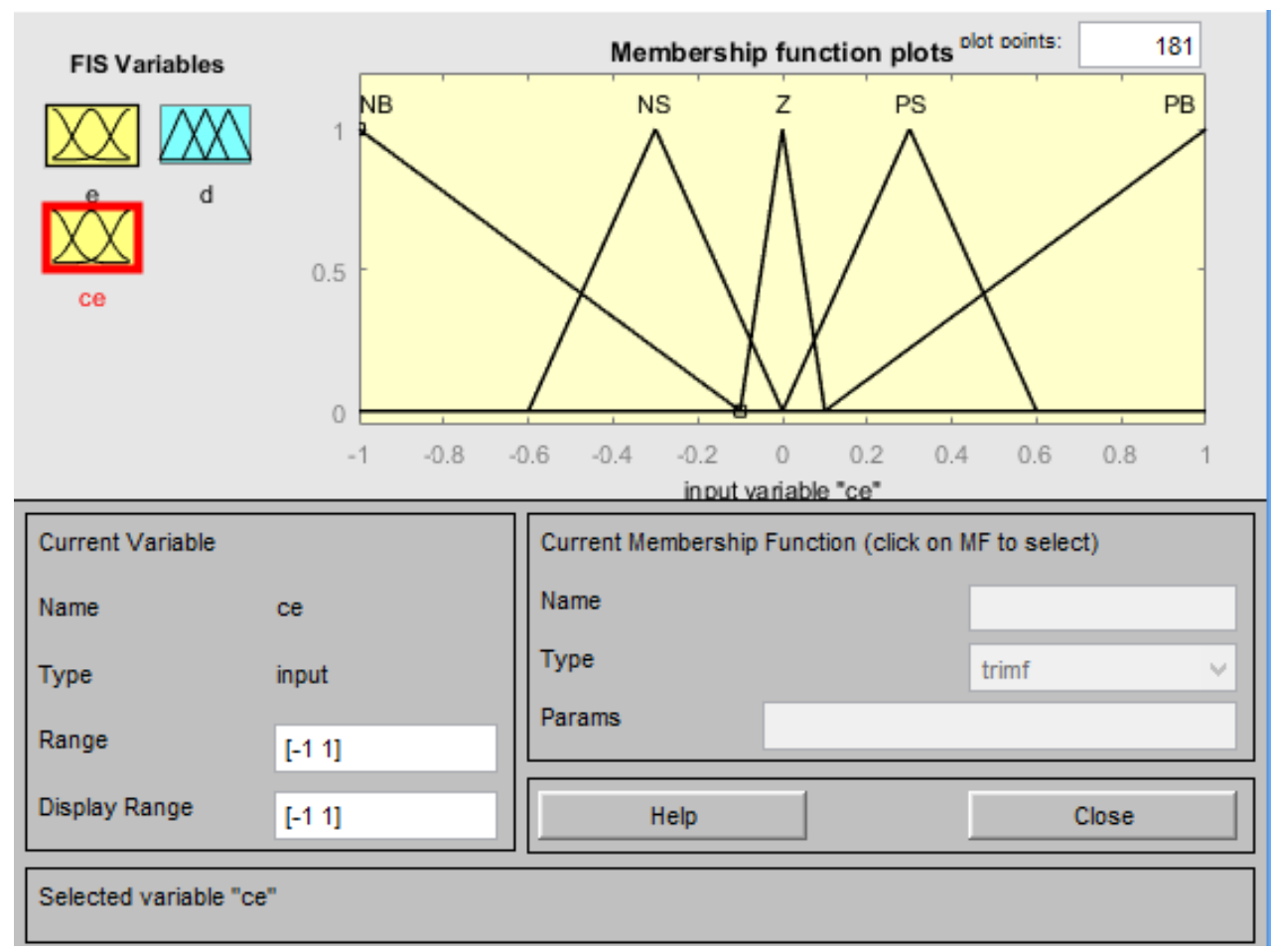

Figure 11."Change of Error" input membership functions for fuzzy logic.

The membership functions determined for the change of error are shown in Figure 11. These functions are $\mathrm{N} / \mathrm{Z} / \mathrm{P}$. 
The membership functions determined for the output are shown in Figure 12. These functions are: NB / NM / NS / Z / PS / PM / PB.

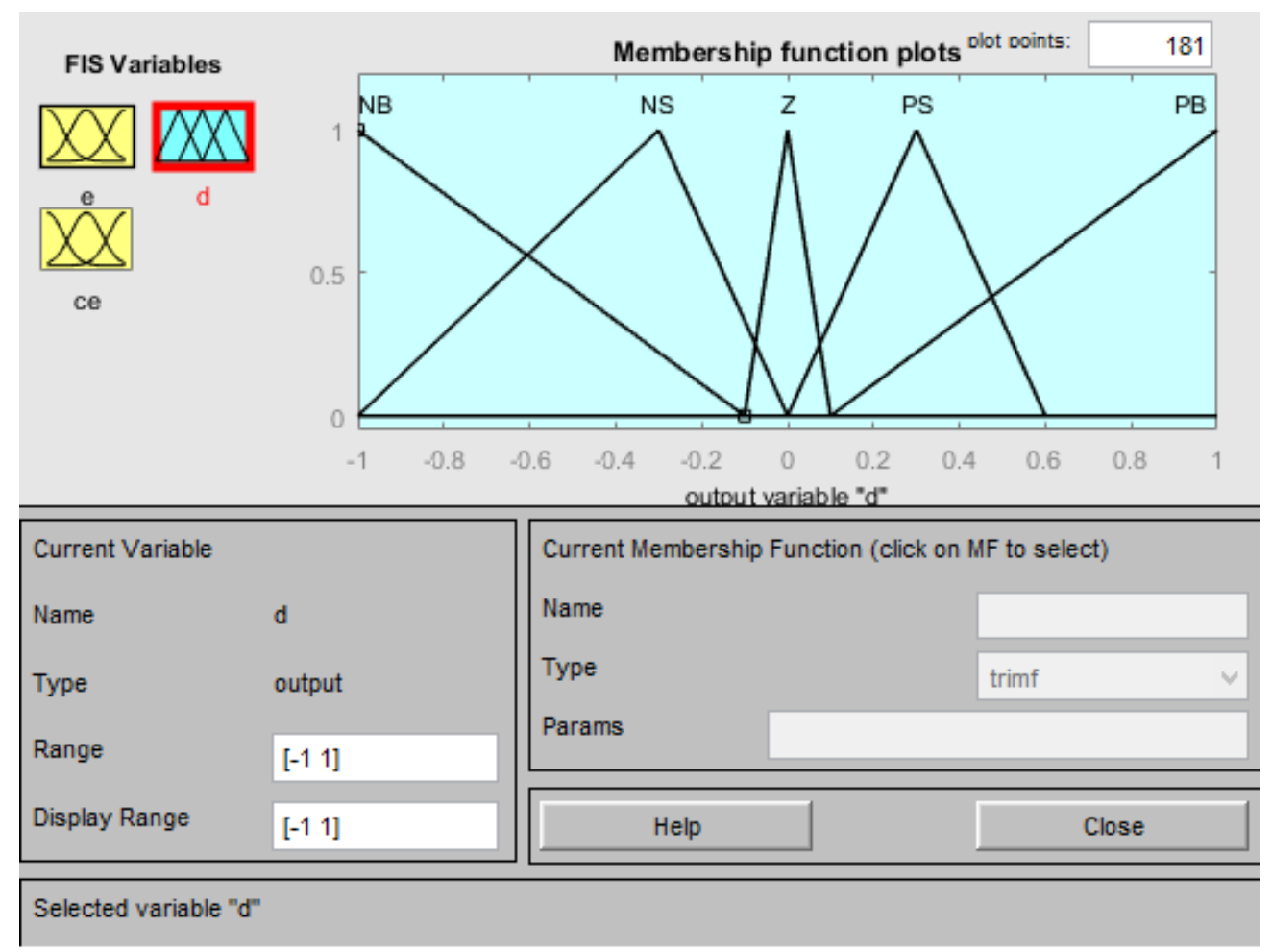

Figure 12. Output change" membership functions for fuzzy logic. After the inputs, outputs and membership functions are specified, rules are set.

Table 1. Fuzzy rules.

\begin{tabular}{|l|l|l|l|l|l|}
\hline \multicolumn{1}{|c|}{ e } & NB & NS & ZO & PS & PB \\
\hline NB & NB & NB & NB & NS & ZO \\
\hline NS & NB & NB & NS & ZO & PS \\
\hline ZO & NB & NS & ZO & PS & PB \\
\hline PS & NS & ZO & PS & PB & PB \\
\hline PB & $\mathbb{Z O}$ & PS & PB & PB & PB \\
\hline
\end{tabular}

\subsection{De-Fuzzificition}

The linguistic variables are converted a numerical variable in this operation. There are different defuzzificition methods. The centroid method is utilized for de-fuzzificition in this article [23].

\section{Matlab /Simulink Model of Fuzzy Logic}

Figure 13 shows the Simulink model of the proposed boost converter with fuzzy logic control. PWM generated with fuzzy control is delivered to dc-dc converter. The reference voltage is the output voltage and its value is $200 \mathrm{~V}$. The values of input voltage are between $45 \mathrm{~V}$ and $60 \mathrm{~V}$. 

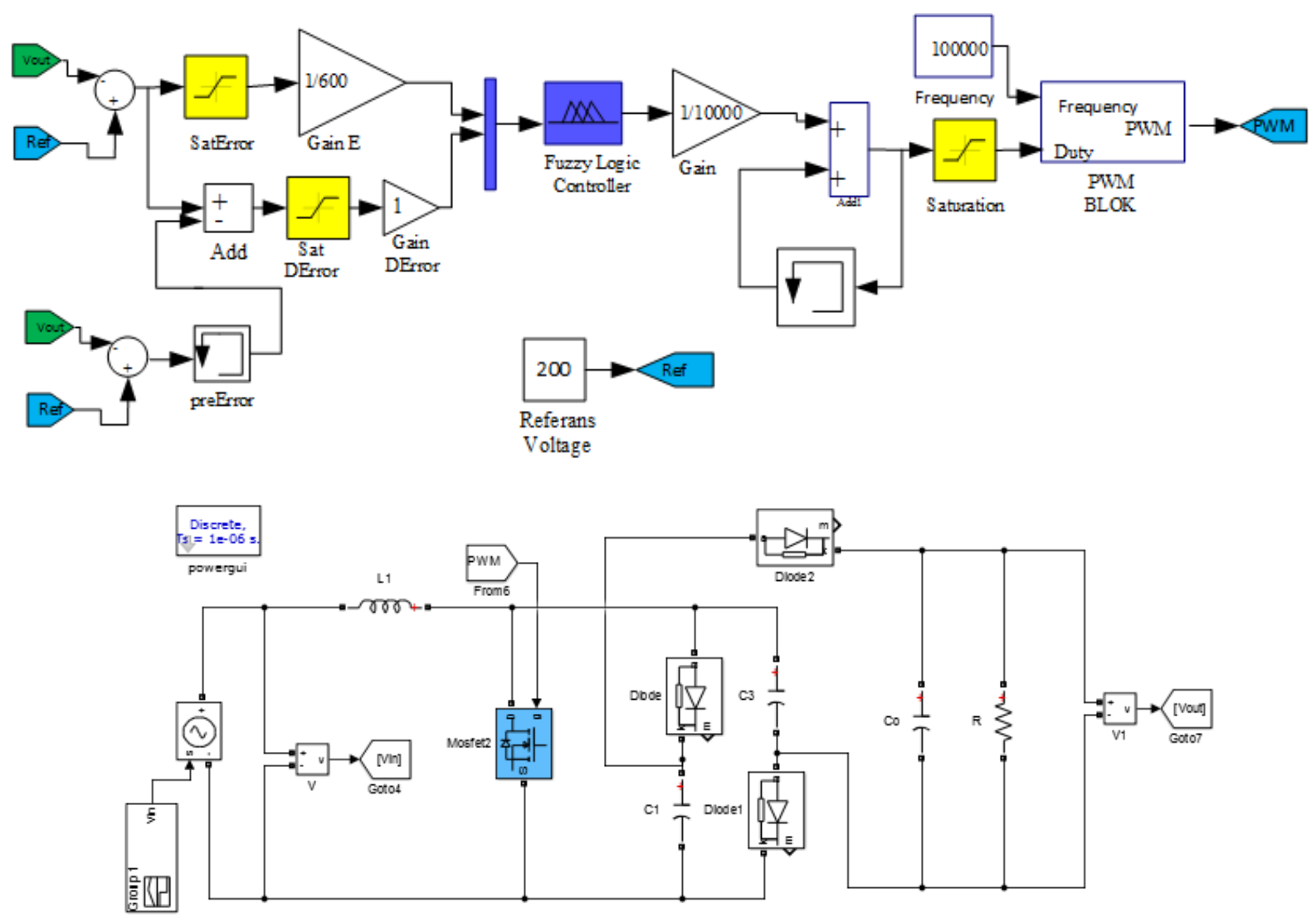

Figure 13. MATLAB/Simulink model of proposed boost converter with Fuzzy logic control.

\section{Designing the Control Model of PI}

The PI control utilizes the present error input and the past error for control. It requires two adjustable parameters for the faster response, reducing the steady-state error to zero or decreasing it to a smaller tolerance limit.

In this part, designing the control model of PI is explicated with a dynamical model of the circuit. At the point when the switch is in ON state, the state spaces conditions are as per the following, where $\mathrm{V}_{\mathrm{o} 1}$ is the voltage of drain-source pins of the MOSFET, and $\mathrm{V}_{\mathrm{O}}$ is equal to $2 \mathrm{~V}_{\mathrm{o}}$, because $\mathrm{SC}$ piece of the structure increases the converter's voltage gain to two times.

$$
\begin{gathered}
\frac{d V_{01}}{d t}=-\frac{V_{01}}{R C_{0}} \rightarrow \frac{d V_{01}}{d t}=-\frac{V_{01}}{R C_{0}} \\
C_{1} \frac{d V_{C 1}}{d t}=i_{L} \rightarrow \frac{d V_{C 1}}{d t}=\frac{i_{L}}{C_{1}} \\
C_{2} \frac{d V_{C 2}}{d t}=i_{L} \rightarrow \frac{d V_{C 2}}{\mathrm{dt}}=\frac{\mathrm{i}_{\mathrm{L}}}{\mathrm{C}_{2}} \\
C_{0} \frac{d V_{01}}{d t}=-\frac{V_{01}}{R} \rightarrow \frac{d V_{01}}{d t}=-\frac{V_{01}}{R C_{0}}
\end{gathered}
$$

When the switch is in OFF state, the equations is as follows;

$$
\begin{aligned}
& L \frac{d i_{L}}{d t}=\left(V_{i n}-V_{C 1}\right)(1-d) \rightarrow \frac{d i_{L}}{d t}=\frac{\left(V_{i n}-V_{C 1}\right)}{L}(1-d) \\
& C_{1} \frac{d V_{C 1}}{d t}=-\frac{i_{L}}{2}(1-d) \rightarrow \frac{d V_{C 1}}{d t}=\frac{i_{L}}{2 C_{1}}(1-d)
\end{aligned}
$$




$$
\begin{gathered}
C_{2} \frac{d V_{C 2}}{d t}=-\frac{i_{L}}{2}(1-d) \rightarrow \frac{d V_{C 2}}{d t}=\frac{i_{L}}{2 C_{2}}(1-d) \\
C_{0} \frac{d V_{01}}{d t}=\left(i_{L}-\frac{V_{01}}{R}\right)(1-d) \rightarrow \frac{d V_{0}}{d t}=\frac{i_{L}}{C_{01}}-\frac{V_{01}}{C_{0} R}(1-d)
\end{gathered}
$$

If the on and off modes are used together, the following equations are obtained;

$$
\begin{gathered}
\frac{d L}{d t}=\frac{V_{\text {in }}}{L}-\frac{V_{C 1}}{L}(1-d) \\
\frac{d V_{01}}{d t}=-\frac{V_{01}}{C_{0} R}+\frac{i_{L}}{C_{0}}(1-d) \\
\frac{d V_{C 1}}{d t}=-\frac{i_{L}}{C_{1}}+\frac{i_{L}}{2 C_{1}}(1-d) \\
\frac{d V_{C 2}}{d t}=\frac{i_{L}}{C_{2}}+\frac{i_{L}}{2 C_{2}}(1-d)
\end{gathered}
$$

For the PI controller, finding a relationship between the output voltage and the inductor current derivative or one of the capacitor voltage derivatives is important. This situation is expressed in Equation (29) and (30), and it can be obtained from (24) [17].

$$
\begin{gathered}
C_{0} \frac{d V_{01}}{d t}+\frac{V_{01}}{R}=\left(i_{L}\right)(1-d)=u,\left(V o=2 V_{01}\right) \\
\operatorname{CoS} \frac{V o}{2}+\frac{1}{R} \frac{V o}{2}=V o\left(\frac{C o S}{2}+\frac{1}{2 R}\right)\left(i_{L}\right)(1-d)=u \\
d=1-\frac{u}{I_{L}}
\end{gathered}
$$

In PI control, to fix the output voltage of proposed converter is aimed. For this purpose, the reference voltage sampling is compared with the reference voltage. After the sampled voltage passes the controller, the controller output $(\mathrm{u})$ is compared with the inductor current and the duty cycle of PWM is provided according to Equation (31). The control block diagram is showed with the PI controller Figure 14.

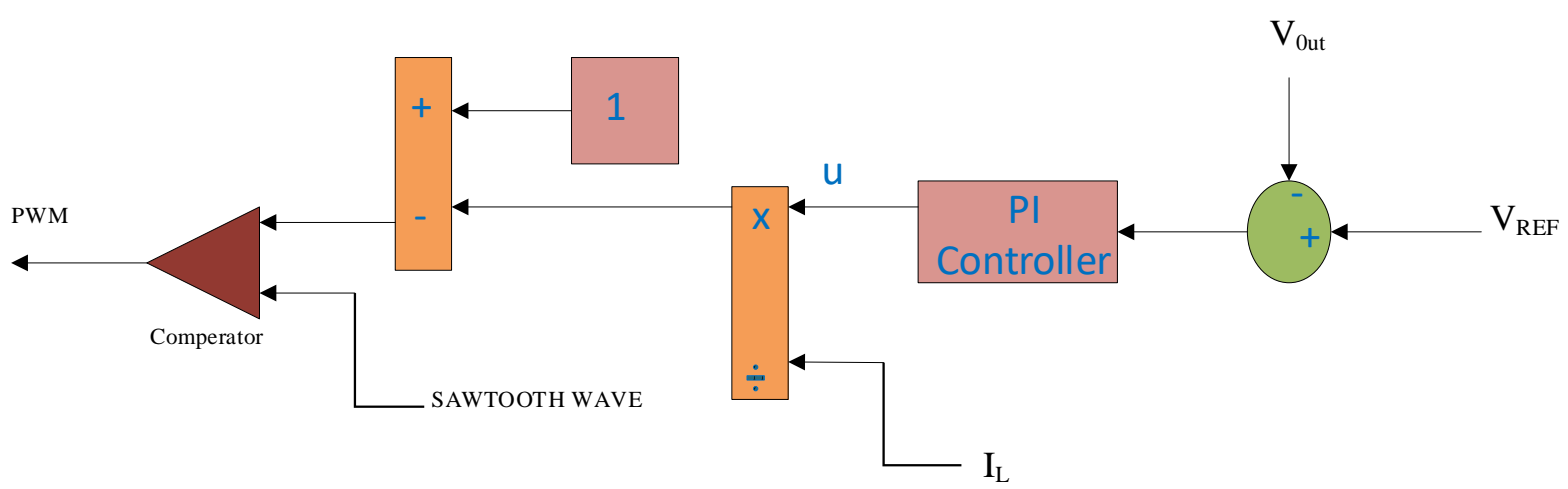

Figure 14. PI type controller block diagram.

The common expression for PI controller is as Equation (32). 


$$
G(s)=k p+\frac{k_{i}}{s}=\frac{k_{p} s+k_{i}}{s}
$$

The PI controller controls utilizing the reference voltage at the input. Figure 15 demonstrates a closed loop diagram of PI controller according to Equation (30).

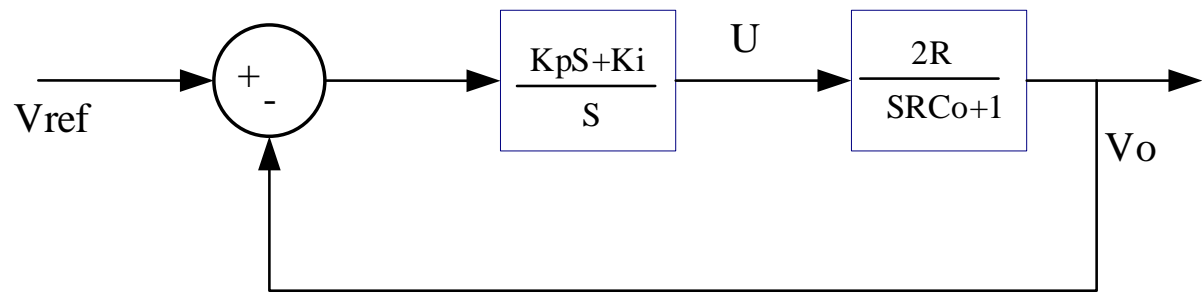

Figure 15. Closed loop diagram of PI controller.

In Equation (33), the transfer function for closed-loop is shown.

$$
G F=\frac{G_{O}}{1+G_{O}}=\frac{\frac{2}{C_{0}}\left(k_{p}+k_{i}\right)}{S^{2}+\left(\frac{1+2 R k_{p}}{R C_{0}}\right) S+\frac{2 k_{i}}{C_{0}}} \quad \rightarrow \quad G F=\frac{\frac{2}{C_{0}}\left(k_{p} s+k_{i}\right)}{s^{2}+2 \xi \omega_{o} s+\omega_{o}^{2}}
$$

$\mathrm{k}_{\mathrm{p}}$ (proportional coefficient) and $\mathrm{k}_{\mathrm{i}}$ (integral coefficient) are as per the following;

$$
\left\{\begin{array} { c } 
{ \frac { 1 + 2 R k _ { p } } { R C _ { 0 } } = 2 \xi \omega _ { o } } \\
{ \frac { 2 k _ { i } } { C _ { 0 } } = \omega _ { o } ^ { 2 } }
\end{array} \rightarrow \left\{\begin{array}{c}
k_{p}=2 \xi \omega_{o} C_{0}-\frac{1}{R} \\
k_{i}=\omega_{o}^{2} C_{0}
\end{array}\right.\right.
$$

Fluctuation on inductor is explained as;

$$
\Delta i L=\frac{V_{\text {in }}}{L} d T=\frac{\left(V_{\text {in }}-V_{C 1}\right)}{L}(1-d) T
$$

Inductor current is computed as follow;

$$
i_{L}=I_{o}\left(\frac{2}{1-d}\right)
$$

The oscillation of inductor current is explained as equation;

$$
\xi=\frac{\Delta i L / 2}{I_{L}}=\frac{d(1-d) T V_{i n}}{4 L I_{o}}=\frac{d(1-d)^{2}}{4} \cdot \frac{R}{f_{p} \cdot L}
$$

In Equation (38), ripple on capacitor voltage is mentioned.

$$
\varepsilon=\frac{\Delta V_{O} / 2}{V_{O}}=\frac{1-d}{2 R f C_{O}}
$$




\section{Matlab /Simulink Model of PI Controller}

Figure 16 shows Simulink model of proposed boost converter with PI control. Equation (31) and Figure 14 are utilized for the structure of PI controller. Reference and sampling voltages are compared and a saw-tooth wave is used for duty cycle production. Then, PWM generated with PI control is transferred to MOSFET's gate.

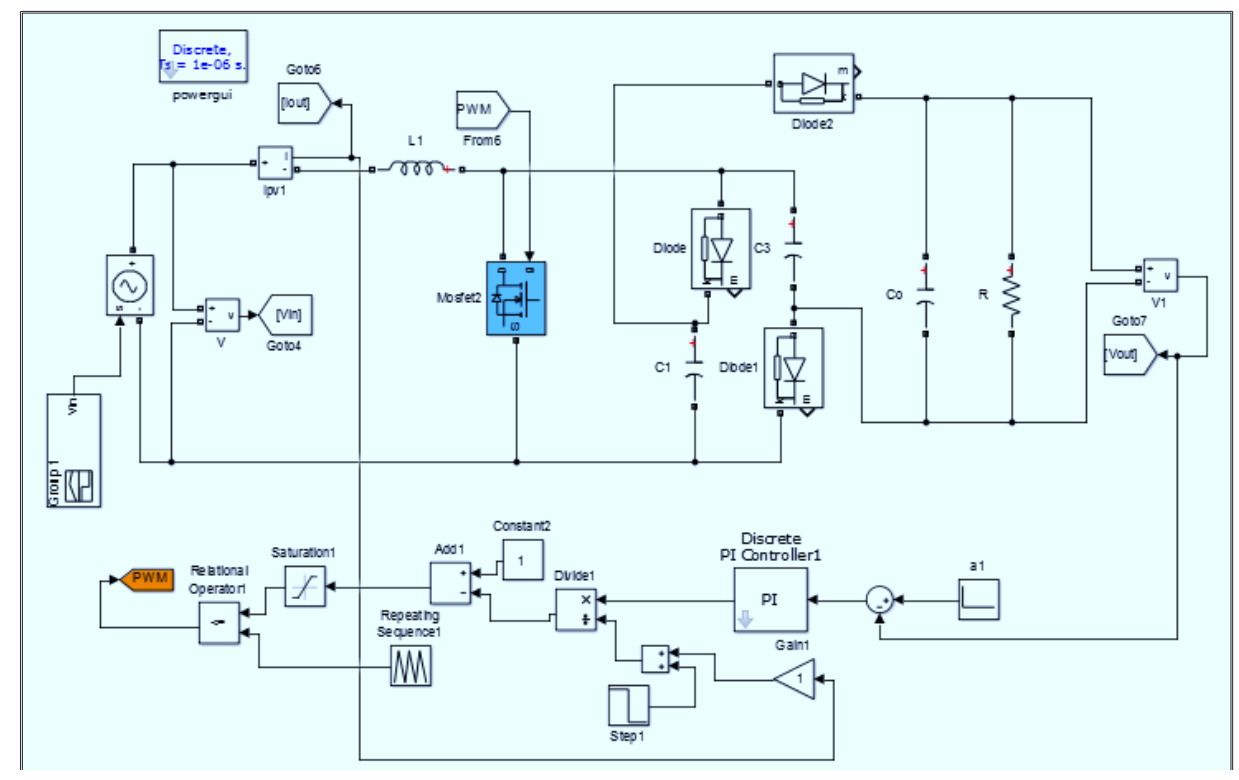

Figure 16. MATLAB/Simulink model of proposed boost converter with PI control.

\section{Simulation Results}

PI and fuzzy logic control have compared with Matlab/Simulink software. Table 2 shows parameter values of the boost converter used in the comparison.

Table 2. The element values of DC-DC converter circuit.

\begin{tabular}{cccccc} 
& $\mathrm{R}(\mathrm{ohm})$ & $\mathrm{L}(\mathrm{mH})$ & $\mathrm{C}_{0}(\mathrm{uF})$ & $\mathrm{C}_{1}, \mathrm{C}_{2}(\mathrm{uF})$ & $\mathrm{f}(\mathrm{kHz})$ \\
\hline Fuzzy & 300 & 0.3 & 333 & 3.3 & 100 \\
PI & 300 & 3.3 & 333 & 3.3 & 100 \\
\hline
\end{tabular}

The output voltage of a well-designed controller doesn't change with different input voltages and remains constant. This situation has been exhibited in simulation. In Figure 15, the output voltage was fixed at $200 \mathrm{~V}$ and the input voltage was changed to $45 \mathrm{~V}, 60 \mathrm{~V}$, and $54 \mathrm{~V}$ in order to test the ability of the controllers to fix the output voltage at the 200VDC and compare the reaction of the investigated controllers. Simulations were carried out at $100 \mathrm{kHz}$ frequency. According to Figure 17, the fuzzy controller has shorter settlement time and reaches stability faster. Fuzzy logic controller gives much better results in changing conditions, because it depends on rule base and ability to make decisions. But beside the damping problem for the PI controller, this figure shows that the overshoot or undershoot values for this controller is less in comparison to the Fuzzy logic controller for the larger change amplitudes. Also, the transient time for the controller are interesting and where the PI controller increases the output voltage exponentially, the fuzzy controller experiences quick under and overshoots with high amplitudes. 


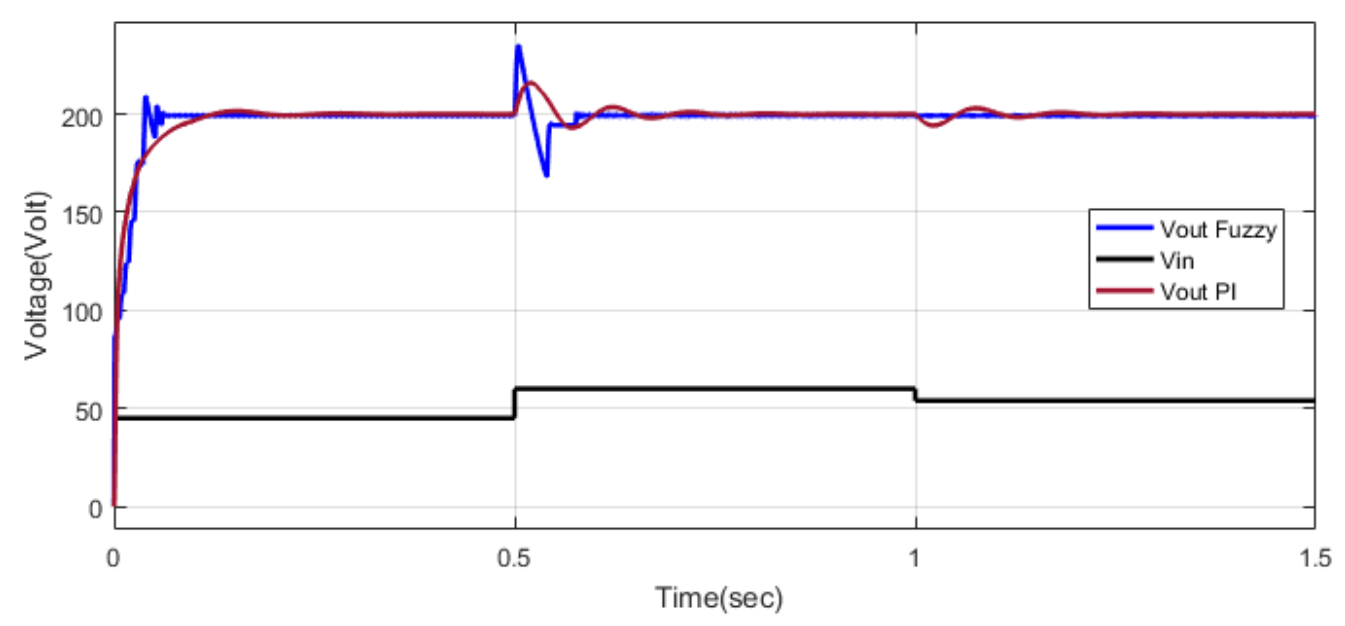

Figure 17. Comparison of output voltage.

Figure 18 and Figure 19 shows a comparison of output power and current, respectively. Output power is 130Watt. One of the features of a well-designed converter is to ensure the stability of the output power and current in changing input voltages. The output current is very low for both controllers. At the moments that the input voltage changes, Fuzzy controller has bigger ripple than PI controller but, the PI controller reacts slowly and more soft to prevent irregular changes.

Figure 20 shows inductor current fluctuations at different input voltages. Accordingly, the transmission time of the switch increases at low input voltage, which leads to transmission losses that occurs in transition to $\mathrm{ON}$ and $\mathrm{OFF}$ states and more inductor current fluctuations. High transmission loss in fuzzy controller causes the increasing of inductor current fluctuation. According to the simulation result, it is seen that the inductor current fluctuation is smaller at PI controller, since this approach is based on the pure and accurate mathematical model for the examined converter. Also, Fuzzy controls make bigger ripple at the start time. On the other hand, PI has smaller ripple and then immediately settles to the desired value at the moments that the input voltage changes, the PI controller reacts more soft to prevent irregular changes.

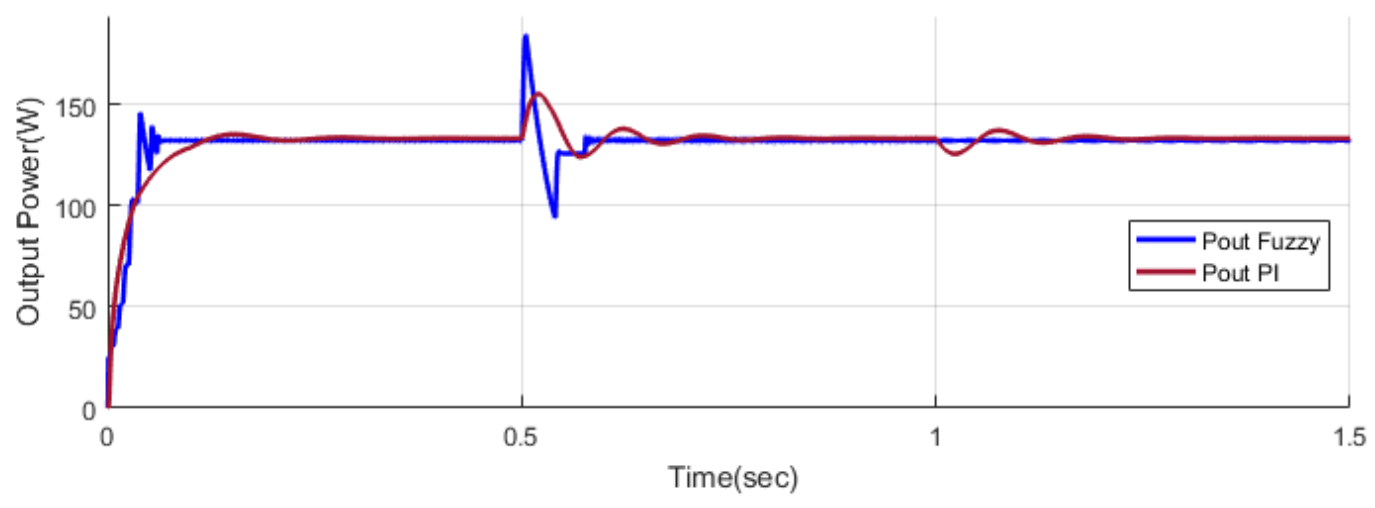

Figure 18. Comparison of output power. 


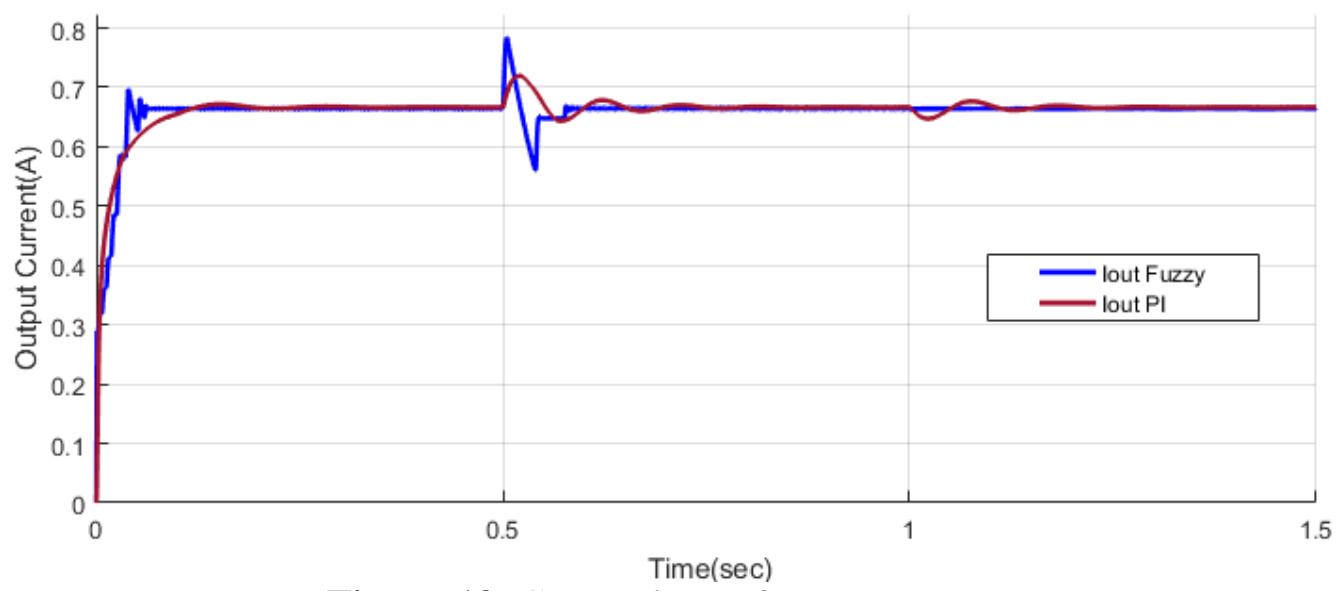

Figure 19. Comparison of output current.

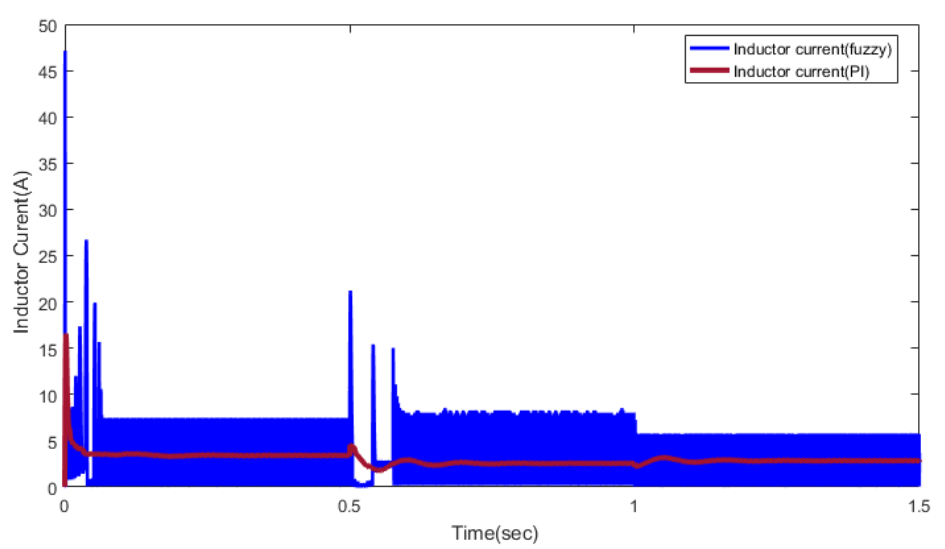

Figure 20. Comparison of inductor current for input voltage of $45 \mathrm{~V}, 60 \mathrm{~V}, 54 \mathrm{~V}$.

The output voltage of the recommended converter fixed at $200 \mathrm{~V}$ and voltage on the switched capacitor is half of the output voltage according to Figure 21. In SC cell boost converters, when the switch is in the OFF mode, the sum of the $\mathrm{C} 1$ and $\mathrm{C} 2$ capacitor voltages is equal to the output voltage due to the parallel connection. This means that the $\mathrm{C} 1$ capacitor voltage is doubled at the output. Also, the proposed converter is obtained from the conventional boost converter by adding a 2 -stage SC cell to increase the voltage to two times. Where SC cell provides to obtain higher output voltage for the same duty cycle compared to the conventional boost converter. Figure 21 shows the output voltage and capacitor voltages according to different input voltages. In a well-designed controller, the SC capacitor voltages should not be affected by different input voltages. This situation is shown in the simulation.

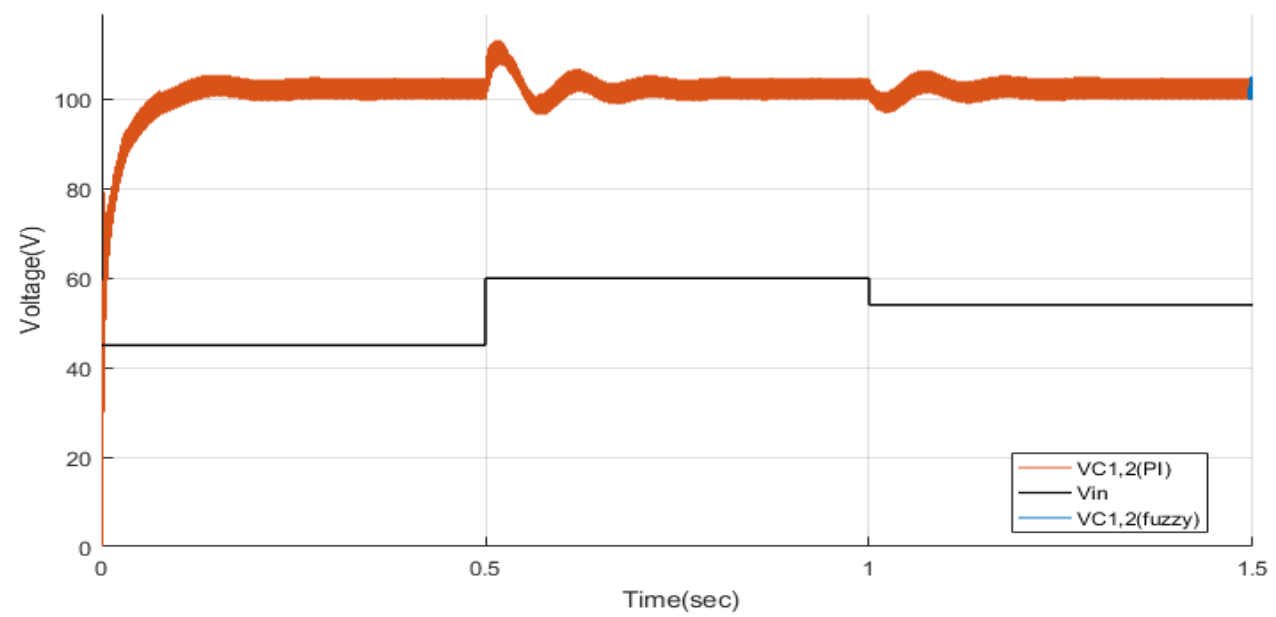

Figure 21. Voltage of switched capacitor $(\mathrm{C} 1, \mathrm{C} 2)$ for input voltage of $45 \mathrm{~V}, 60 \mathrm{~V}, 54 \mathrm{~V}$. 
Figure 22 illustrates pulses which produce by a controller for various input voltages. A lower duty cycle is preferred to reduce switching losses in applications and according to the figure, the Fuzzy controller has a lower pulse width. At different input voltages and $200 \mathrm{~V}$ constant output voltage, pulses with different duty cycles produced with the controller are applied to MOSFET by the power switch. So, the output voltage remains constant by producing large pulse width at low input voltage and small pulse width at large input voltage. According to simulation results, it is seen that the pulse width is also long at low input voltage. Where, the switched capacitors are charged as parallel by the inductor and discharged as series for high voltage gain and provides to overcome the problem of sudden voltage emergent because of leakage inductance. So, the drop rate of the current on output diode decreases, and then switching loss on diodes is reduced. Also, conduction losses can be decreased by using small values of semiconductor elements. Here, the inductor value of PI is 3.3 $\mathrm{mH}$, and the inductor value of Fuzzy control is $0.3 \mathrm{mH}$.

Figure 23 presents the average level of the implemented duty cycles by both controllers. This figure shows that the Fuzzy Logic Controller can drive the power switch under less duty cycle to fix the output voltage. But at the moments that the input voltage changes, the PI controller reacts softer and prevent irregular changes. This controller changes the duty cycle exponentially. Also, by this figure one can see the approaches of the controllers are completely different for the start time and where the Fuzzy controller changes from zero to the desired duty cycle value, the PI controller increases the duty ratio to one and, then decreases to the related value. In DC-DC converters, the control is provided by changing the transmission time with PWM (Pulse Width Modulation) method. D (duty cycle) takes a value between $0-1$. If $\mathrm{D}$ is low, the power received from the converter is low, when $\mathrm{D}$ is high, the received power also increases. Switching is important in PWM. For this, increasing the frequency provides more efficiency.

Figure 24 exhibits a comparison of voltage gain for different input voltages. When Figure 24 is examined, the fuzzy logic indicates that the controller provides a lower voltage gain to achieve constant output voltage. However, to prevent sudden changes, the PI controller responds more softly when the input voltage changes, and but the parasitic effect of elements has caused the desired and obtained voltage gain values are different. Also, both PI and Fuzzy controllers behave differently at the beginning times. The PI controller increases the voltage gain by 35 times and then decreases to the desired value while the Fuzzy controller places to the desired value.

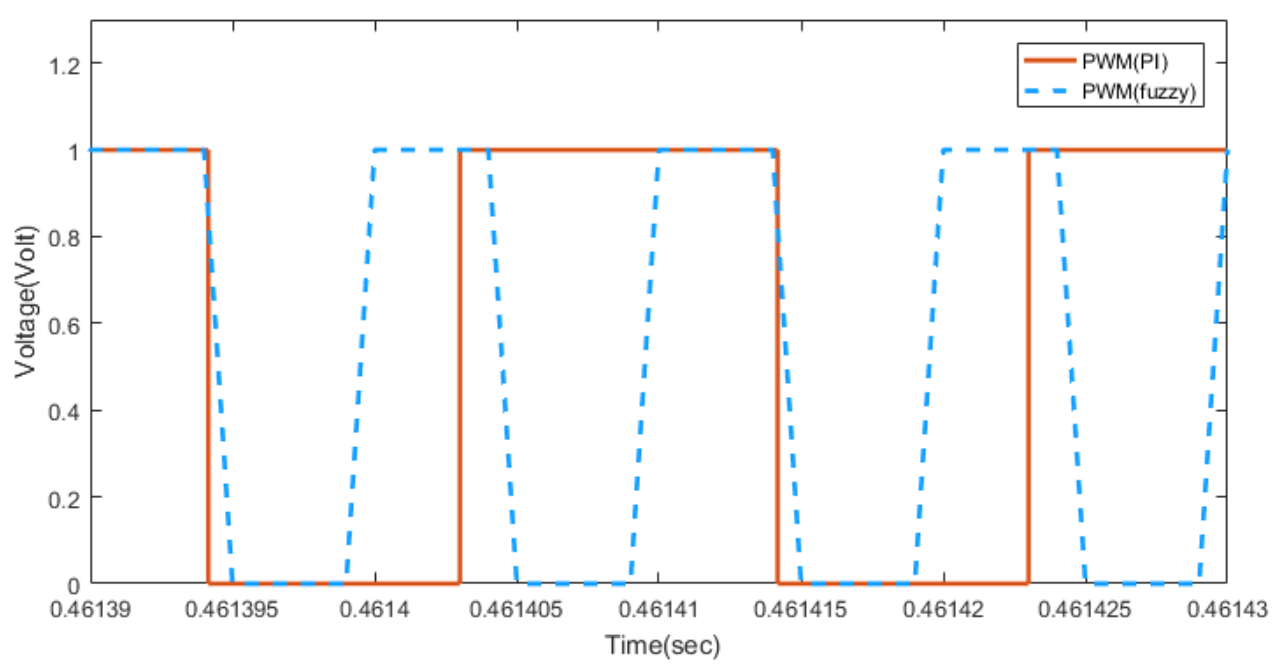

(a) 


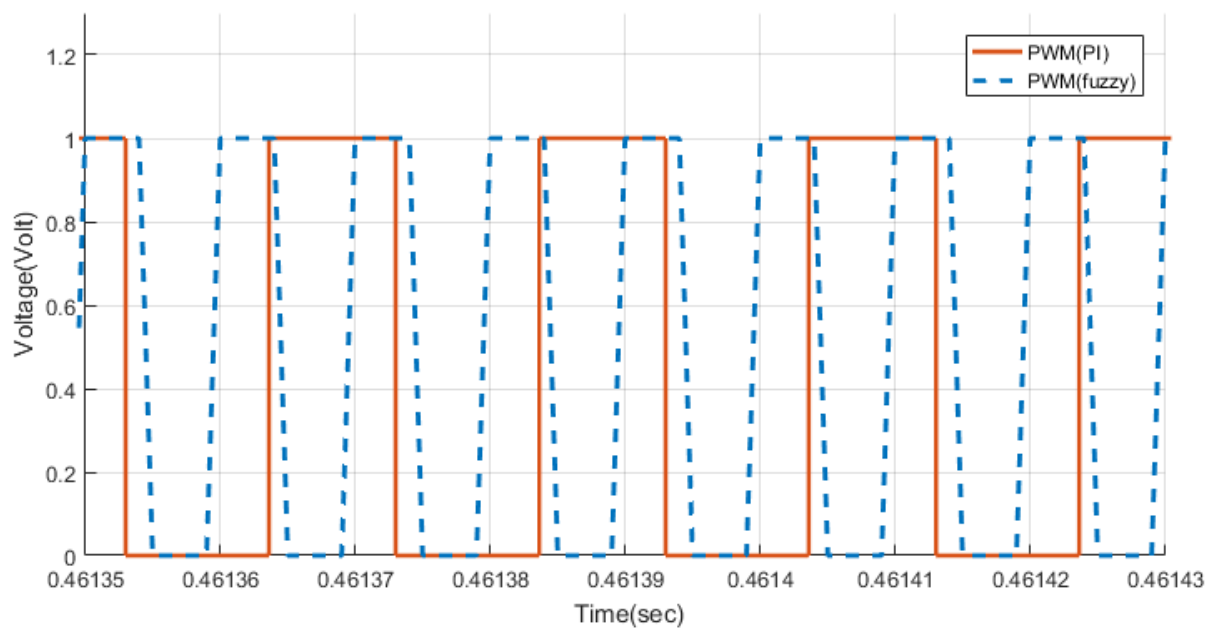

(b)

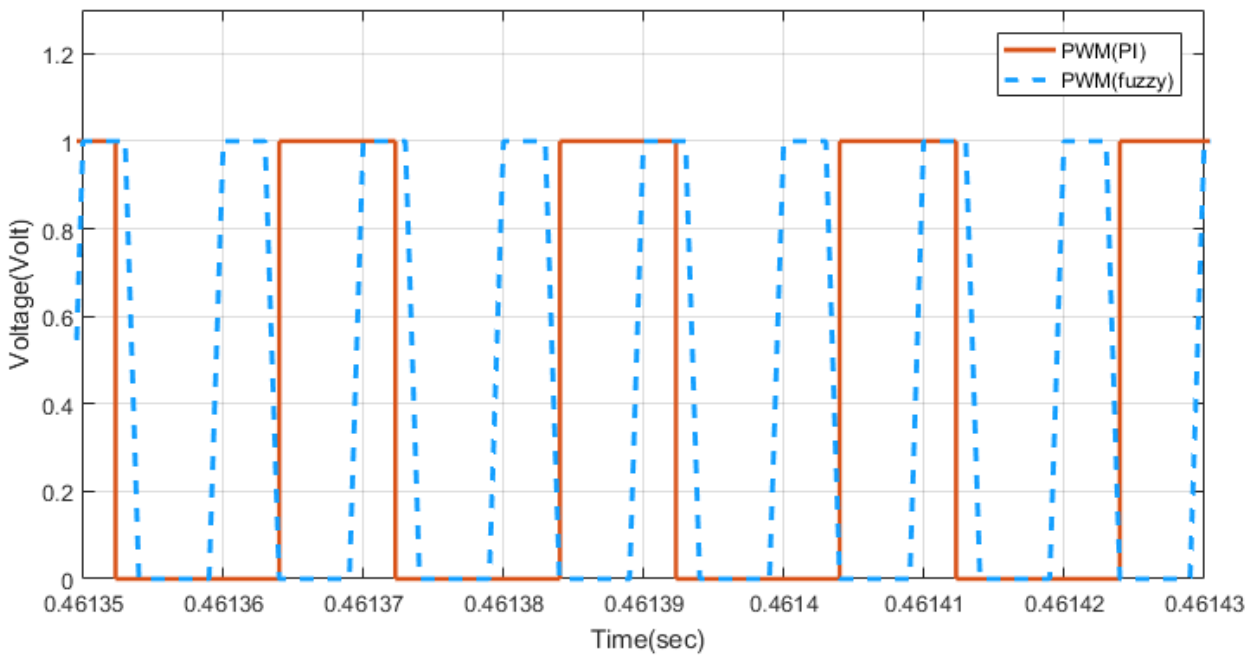

(c)

Figure 22. PWM with PI and Fuzzy logic controller for input voltage of a) 45V, b) 54V, C) $60 \mathrm{~V}$.

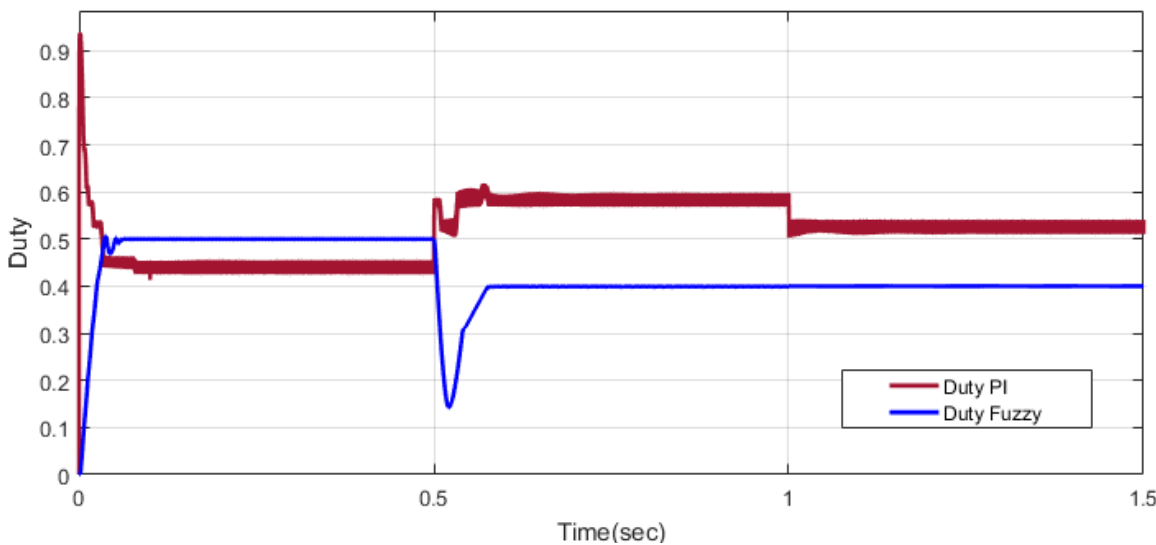

Figure 23. Comparison of duty for input voltage of $45 \mathrm{~V}, 60 \mathrm{~V}, 54 \mathrm{~V}$. 


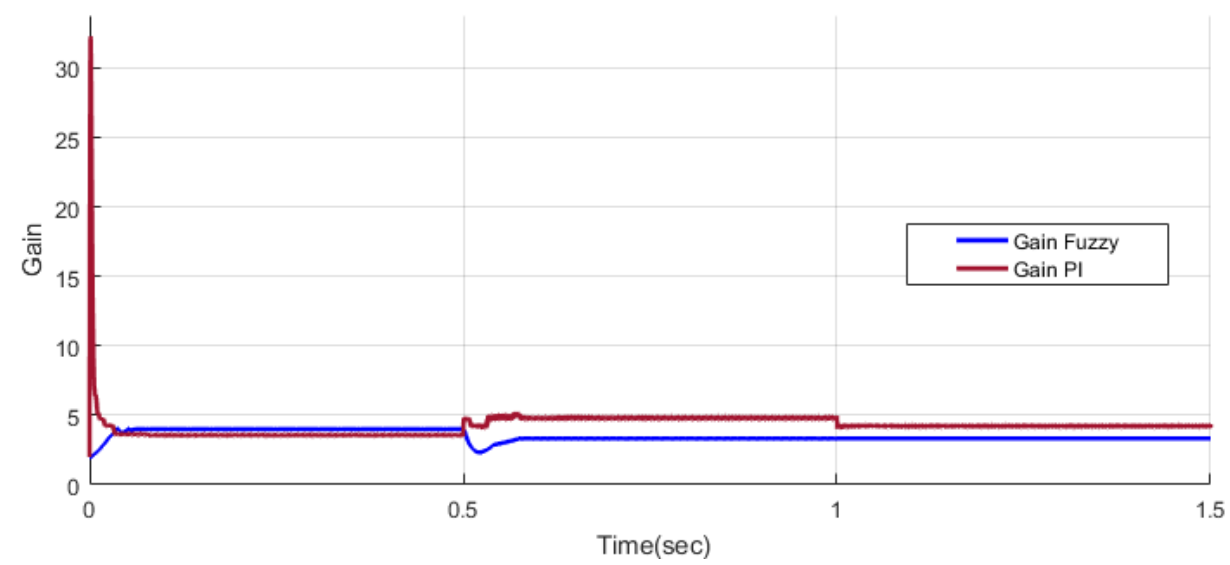

Figure 24. Comparison of gain for input voltage of $45 \mathrm{~V}, 60 \mathrm{~V}, 54 \mathrm{~V}$.

Figures 25, 26, and 27 show the efficiency waveform according to output power for 45,54 and $60 \mathrm{VDC}$ of the input voltages, respectively. When the efficiency change graph is examined, fuzzy controller performance changes slightly in variable power values. According to the figure, the fuzzy control is more suitable than PI for both low and high powers. Because PV panels provide limited power, the power must be transferred to the consumer via an efficient converter. Although the proposed converter is costlier than the conventional converter, the balance between efficiency and voltage gain is reasonable and the structure has become more efficient with fuzzy control. However, efficiency decreases with the increasing input voltages in the PI controller. The main reason for the decrease of efficiency in the PI control is that the power loss on the output diode is related to current. Diode losses are observably noticeable at high current. The fuzzy controller has more performances until 130W as power loss on the diode is smaller.

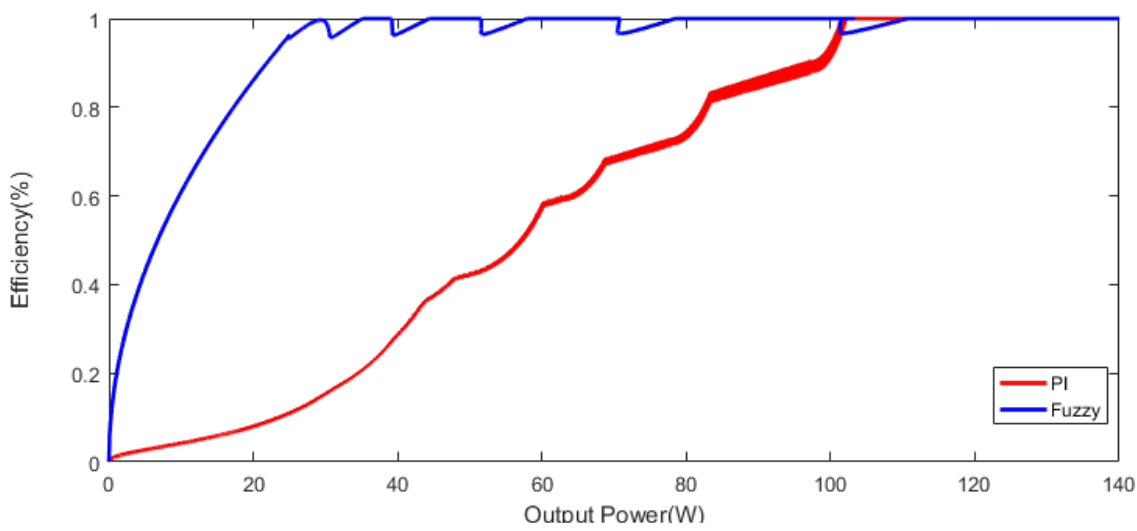

Figure 25. Comparison of efficiency and output power for input voltage of $45 \mathrm{~V}$.

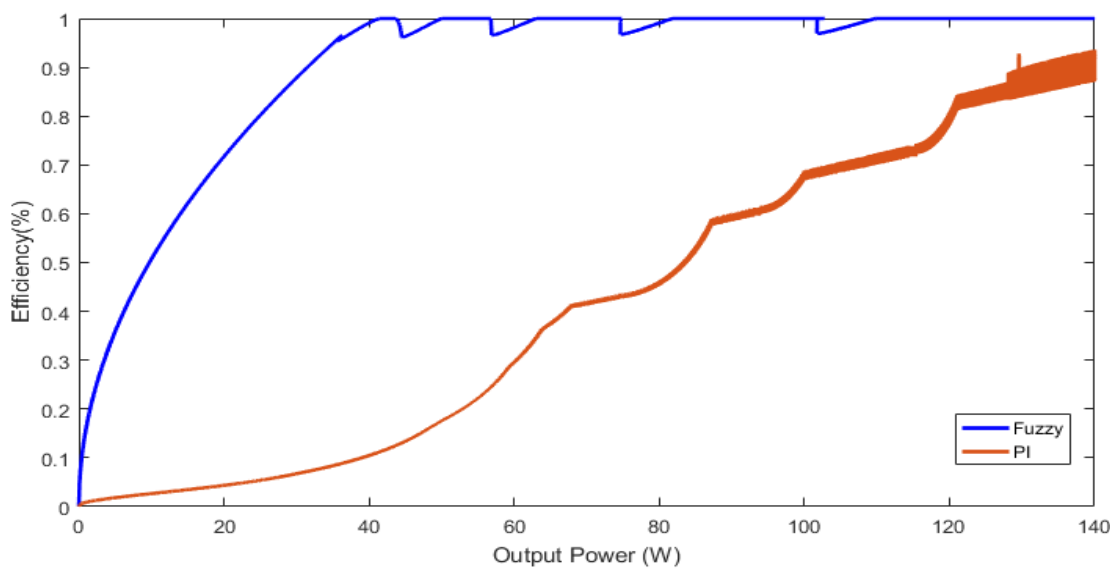

Figure 26. Comparison of efficiency and output power for input voltage of $54 \mathrm{~V}$. 


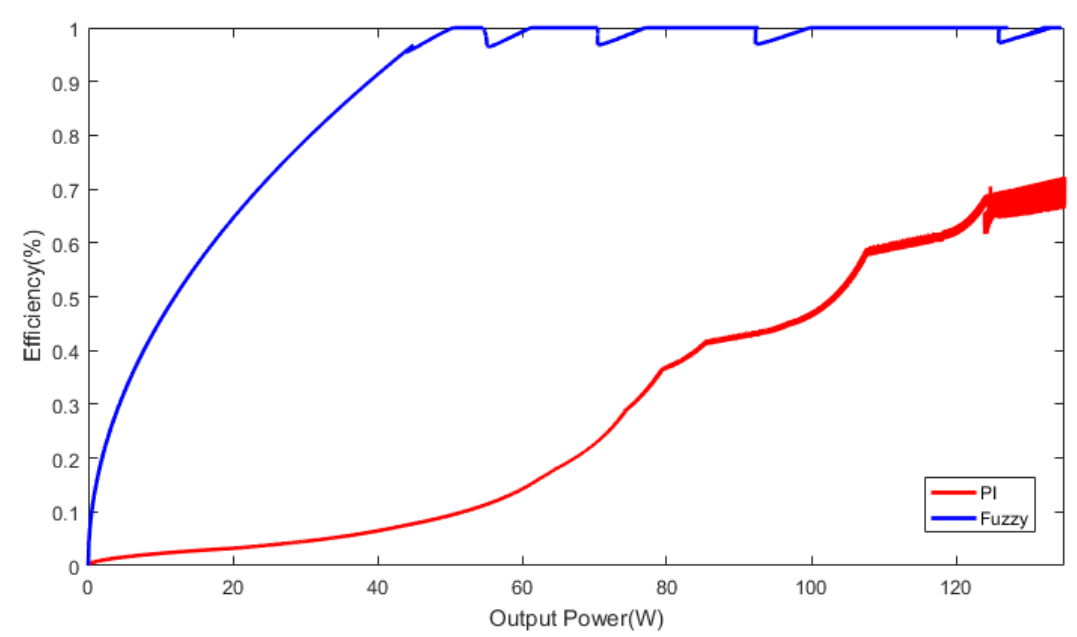

Figure 27. Comparison of efficiency and output power for input voltage of 60V.

\section{Conclusions}

In this study, a 2-stage SC cell-based boost converter with PI and Fuzzy Logic controllers has been compared in terms of efficiency and voltage gain. The controller construction is used to raise the stability and efficiency of the distinct input voltages. Since the tested converter consists of fewer components, it is a low cost, and being the only switch in its structure provides ease of control. Using a single MOSFET provides that control is needed and therefore system clutter is prevented. Also, since fuzzy logic control depends on the rule base and fast system response in changing conditions, it is important for applications. In this way, the fuzzy logic controller is more appropriate than the PI controller for converters with the complex mathematical model, because the PI controllers need a comprehensive mathematical model and also need a transfer function between the output voltage and duty cycle of the switch.

On the other hand, although the fuzzy boost converter's voltage gain is lower, it provides the same voltage gain at a lower pulse width compared to the PI controller, so efficiency is balanced. At the same time, this converter has the characteristics of a well-controlled converter, as it ensures the stability of the output voltage in sudden changes in output load, and input voltage.

As can be seen from the studies performed with the MATLAB simulation program, Fuzzy Logic control can be selected for such converters since the approach of this controller is based on fuzzy rules and does not need a model of the converter. The disadvantage of the proposed converter is the fluctuations in the input current, but due to converter performance, this situation can be neglected.

All these reasons allow the 2-stage SC cell boost based fuzzy logic control converter to be preferred instead of many boost converters for high-performance applications.

\section{Acknowledgements}

This work is the results of the Master Thesis of Mrs. Kübra BULUT under the supervisory of the Asst. Prof. Dr. Davood GHADERI in Electrical and Electronics Engineering Department of Bursa Technical University, Bursa, Turkey. This research was funded by a grant (No. 190Y018) from the Scientific Research Projects Units of Bursa Technical University, Bursa, Turkey 


\section{References}

[1]. Spring, G. Wirth, G. Becker, R. Pardatscher and R. Witzmann, "Grid Influences From Reactive Power Flow of Photovoltaic Inverters With a Power Factor Specification of One," in IEEE Transactions on Smart Grid, vol. 7, no. 3, pp. 1222-1229, May 2016, DOI: 10.1109/TSG.2015.2413949.

[2]. A. Sangwongwanich and F. Blaabjerg, "Mitigation of Interharmonics in PV Systems with Maximum Power Point Tracking Modification," in IEEE Transactions on Power Electronics, vol. 34, no. 9, pp. 8279-8282, Sept. 2019, doi: 10.1109/TPEL.2019.2902880.

[3]. D. GHADERI, D. Molaverdi, A. Kokabi, and B. Papari, "A Multi Phase Impedance Source Inverter with an Improved Controller Structure," ELECTRICAL ENGINEERING, pp. 0-0, Mar. 2020.

[4]. H. D. Tafti, C. D. Townsend, G. Konstantinou and J. Pou, "A Multi-Mode Flexible Power Point Tracking Algorithm for Photovoltaic Power Plants," in IEEE Transactions on Power Electronics, vol. 34, no. 6, pp. 5038-5042, June 2019, DOI: 10.1109/TPEL.2018.2883320.

[5]. M. Lei et al., "An MPC-Based ESS Control Method for PV Power Smoothing Applications," in IEEE Transactions on Power Electronics, vol. 33, no. 3, pp. 2136-2144, March 2018, DOI: 10.1109/TPEL.2017.2694448.

[6]. Y. Jeon, H. Lee, K. A. Kim and J. Park, "Least Power Point Tracking Method for Photovoltaic Differential Power Processing Systems," in IEEE Transactions on Power Electronics, vol. 32, no. 3, pp. 1941-1951, March 2017, DOI: 10.1109/TPEL.2016.2556746.

[7]. H. D. Tafti, A. Sangwongwanich, Y. Yang, J. Pou, G. Konstantinou and F. Blaabjerg, "An Adaptive Control Scheme for Flexible Power Point Tracking in Photovoltaic Systems," in IEEE Transactions on Power Electronics, vol. 34, no. 6, pp. 5451-5463, June 2019, DOI: 10.1109/TPEL.2018.2869172.

[8]. J. Wang, K. Sun, H. Wu, L. Zhang, J. Zhu and Y. Xing, "Quasi-Two-Stage Multifunctional Photovoltaic Inverter with Power Quality Control and Enhanced Conversion Efficiency," in IEEE Transactions on Power Electronics, vol. 35, no. 7, pp. 7073-7085, July 2020, DOI: 10.1109/TPEL.2019.2956940.

[9]. Bayrak G.; Ghaderi D. An Improved Step-Up Converter with a Developed Real-Time FuzzyBased MPPT Controller for PV-based Residential Application, International Transactions on Electrical Energy Systems, 2019, DOI: 10.1002/2050-7038.12140

[10]. S. Kolesnik et al., "Solar Irradiation Independent Expression for Photovoltaic Generator Maximum Power Line," in IEEE Journal of Photovoltaics, vol. 7, no. 5, pp. 1416-1420, Sept. 2017, DOI: 10.1109/JPHOTOV.2017.2713404.

[11]. B. Wu, S. Li, Y. Liu and K. Ma Smedley, "A New Hybrid Boosting Converter for Renewable Energy Applications," in IEEE Transactions on Power Electronics, vol. 31, no. 2, pp. 12031215, Feb. 2016, DOI: 10.1109/TPEL.2015.2420994.

[12]. A. Eslami and T. Ghanbari, "New mathematical model from system standpoint to analyse and mitigate PV leakage current of large PV strings/arrays," in IET Generation, Transmission \& Distribution, vol. 13, no. 4, pp. 543-552, 262 2019, DOI: 10.1049/iet-gtd.2018.5030.

[13]. R. P. Xu, C. Zhang, Y. Xu and Z. Y. Dong, "Rolling horizon based multi-objective robust voltage/VAR regulation with conservation voltage reduction in high PV-penetrated distribution networks," in IET Generation, Transmission \& Distribution, vol. 13, no. 9, pp. 1621-1629, 75 2019, DOI: 10.1049/iet-gtd.2018.5940.

[14]. R. Yan and T. K. Saha, "Investigation of Voltage Stability for Residential Customers Due to High Photovoltaic Penetrations," in IEEE Transactions on Power Systems, vol. 27, no. 2, pp. 651-662, May 2012, DOI: 10.1109/TPWRS.2011.2180741. 
[15]. Y. Li et al., "Power Compensation Control for Interconnection of Weak Power Systems by VSC-HVDC," in IEEE Transactions on Power Delivery, vol. 32, no. 4, pp. 1964-1974, Aug. 2017, DOI: 10.1109/TPWRD.2016.2602890.

[16]. Huang R, Hong F, Ghaderi D. Sliding mode controller-based e-bike charging station for photovoltaic applications. Int Trans Electr Energ Syst. 2020; e12300. DOI: 10.1002/20507038.12300

[17]. D. Ghader, P. Kiran Maroti, P. Sanjeevikumar, J. Bo HolmNielsen, E. Hossain, and A. Nayyar, "A Modified Step Up Converter with Small Signal Analysis Based Controller for Renewable Resource Applications," Applied Sciences-Basel, vol. 10, no. 1, pp. 1-23, Jan. 2020. DOI:10.3390/app10010102

[18]. D. Ghaderı and G. Bayrak, "Performance Assessment of a High Powered Boost Converter for Photovoltaic Residential Implementations," Elektronika Ir Elektrotechnika, vol. 25, no. 6, pp. 40-47, Dec. 2019. DOI: 10.5755/j01.eie.25.6.24825

[19]. D. Ghaderı and G. Bayrak, "A Novel Step Up Power Converter Configuration for Solar Energy Application," Elektronika Ir Elektrotechnika, vol. 3, no. 25, pp. 50-55, Jun. 2019. DOI: $10.5755 / \mathrm{j} 01 . e i e \cdot 25.3 .23676$

[20]. D. Ghaderı, M. Çelebi, M. R. Minaz, and M. Tören, "Efficiency Improvement for a DC DC Quadratic Power Boost Converter by Applying a Switch Turn off Lossless Snubber Structure Based on Zero Voltage Switching ZVS ," Elektronika Ir Elektrotechnika, vol. 24, no. 3, pp. 15-22, Jun. 2018. DOI: 10.5755/j01.eie.24.3.20977

[21]. Asim Amir, Hang Seng Che, Aamir Amir, Ahmad El Khateb, Nasrudin Abd Rahim, Transformerless high gain boost and buck-boost DC-DC converters based on extendable switched capacitor (SC) cell for stand-alone photovoltaic system, Solar Energy, Volume 171, 2018, Pages 212-222, ISSN 0038-092X, DOI :10.1016/j.solener.2018.06.078.

[22]. N. A. Rahim, A. Amir, A. El Khateb, H. S. Che and A. Amir, "Gain and efficiency analysis of 2-stage switched capacitor (SC) boost based dc-dc converter," 4th IET Clean Energy and Technology Conference (CEAT 2016), Kuala Lumpur, 2016, pp. 1-5, DOI: 10.1049/cp.2016.1312.

[23]. H. Rezk, M. Aly, M. Al-Dhaifallah and M. Shoyama, "Design and Hardware Implementation of New Adaptive Fuzzy Logic-Based MPPT Control Method for Photovoltaic Applications," in IEEE Access, vol. 7, pp. 106427-106438, 2019, DOI: 10.1109/Access.2019.2932694. 